\title{
PRINCÍPIOS DE ECOLOGIA DA PAISAGEM E A PRESTAÇÃO DE SERVIÇOS ECOSSISTÊMICOS PARA A MICROBACIA DO RIBEIRÃO DO MANDAQUI
}

\author{
PRINCIPLES OF LANDSCAPE ECOLOGY AND THE PROVISION OF ECOSYSTEM \\ SERVICES FOR THE MICROBASIN OF MANDAQUI WATERSHED
}

\author{
Natalia Rezende Carvalho \\ Engenheira Florestal graduada pela Universidade Federal de Lavras, Minas Gerais \\ E-mail: nat.eng.flor@gmail.com
}

\begin{abstract}
RESUMO
Tanto quem busca por refúgios naturais em condomínios á beira da Mata Atlântica, próximos ao cinturão verde da cidade de São Paulo, quanto os que veem o urbanismo sustentável como uma saída para os desafios da cidade, há um ponto em comum: reafirmar a relação entre ser humano e natureza. Estudos recentes constatam a redução do contato das crianças com o ambiente natural quando comparadas aos seus primogênitos. Quanto menor o contato, menor é a identificação com a natureza e as ações em protegê-la e preserva-la. Pensando na realidade das crianças com o meio urbano, onde é necessário um ambiente saudável para crescer e se desenvolver, propõe-se esta análise sobre o Ribeirão do Mandaqui, na Zona Norte de São Paulo, sob a ótica dos princípios da ecologia da paisagem e da prestação de serviços ecossistêmicos. O Ribeirão do Mandaqui está inserido na Trilha Norte Sul proposta na disciplina AUP5853 - Desenho Ambiental da Faculdade de Arquitetura e Urbanismo de São Paulo e é um importante corpo d'água na proposição de um Corredor Verde no município de São Paulo.
\end{abstract}

Palavras-chave: Serviços Ecossistêmicos; Ecologia da Paisagem; Recomposição Florestal; Trilha Norte Sul; Ribeirão do Mandaqui; Corredor Verde

\begin{abstract}
There is a common element for both those who are looking for natural refuges in condominiums at the edge of the Mata Atlântica, near the green belt of São Paulo City, and those who consider sustainable urbanism as a solution for the challenges of the city: reaffirmation of the relationship between human and nature. Recent surveys
\end{abstract}


show the reduction of contact of children with the natural environment when compared to their first-born. The smaller is the contact, smaller is the identification with nature and the actions to protect and preserve it. Thinking about the situation of children with the urban environment, when a healthy environment is required to grow and develop, it is proposed the present analysis of the Mandaqui Watershed, in the North Zone of São Paulo, from the perspective of landscape ecology principles and the provision of ecosystem services. The Mandaqui Watershed is inserted in the North - South Trail proposed in AUP5853 subject - "Environmental Design" of the Faculty of Architecture and Urbanism of São Paulo and is an important water basin in the proposition of a Green Corridor in São Paulo City.

Keywords: Ecosystem Services; Landscape Ecology; Forest Recomposition; North South Trail; Mandaqui Watershed; Green Corridor.

\section{INTRODUÇÃO}

A partir de uma visão privilegiada do alto da Pedra Grande é possível observar São Paulo de norte a sul, com sua diversa e intensa malha urbana. Inserida na Zona de Uso Intensivo do Parque Estadual da Cantareira, a Pedra Grande recebe curiosos e entusiastas da natureza. A Cantareira é uma Unidade de Conservação que faz parte da Reserva da Biosfera do Cinturão Verde- RBCV da cidade de São Paulo (UNESCO, 1994). A Figura 1 apresenta a RBCV e a sua localização no entorno do município de São Paulo, no sudeste do Brasil.

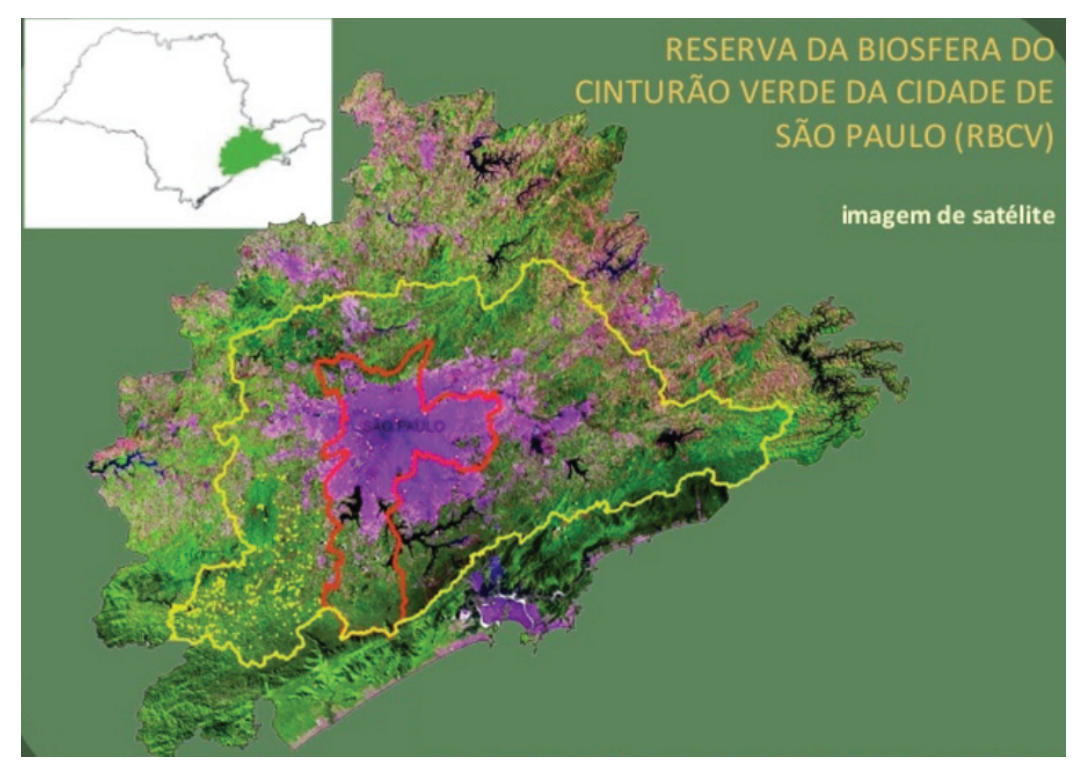

Figura 1 - Localização da Reserva da Biosfera do Cinturão Verde no entorno do município de São Paulo. Fonte: AHPCE em 12/07/16 
Em um primeiro momento é observada a exuberância da Mata Atlântica presente no Parque Estadual da Cantareira, que emoldura de verde a paisagem. O verde se estende da cota $1010 \mathrm{~m}$, no grande afloramento rochoso de granito, até a cota $750 \mathrm{~m}$ no limite de urbanização entre o Horto Florestal e o Bairro do Mandaqui. A partir deste momento, o tecido urbano domina a paisagem e os edifícios tornam-se referências no horizonte. A Figura 2 apresenta ente cenário.

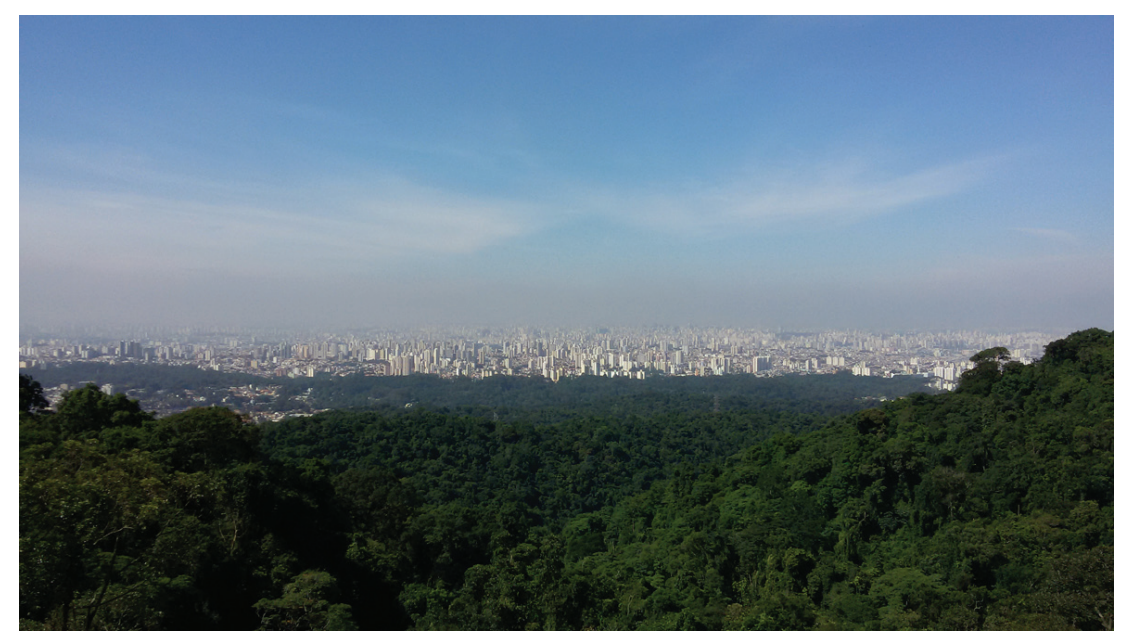

Figura 2 - Visão do município de São Paulo a partir da Serra da Cantareira, na Pedra Grande. Fonte: Natalia Carvalho 21/03/16

O deslocamento entre a Serra da Cantareira e a Várzea do Rio Tietê é realizado através da Avenida Engenheiro Caetano Álvares. Abaixo deste percurso, silenciosamente, escoa as águas do Ribeirão Mandaqui.

Observando este percurso, percebe-se o potencial de transformação da microbacia do Ribeirão do Mandaqui dentro das tendências do urbanismo sustentável, da necessidade de construção de cidades para pessoas e a possibilidade de ganhos ambientais e incremento na qualidade de vida através da prestação de serviços ecossistêmicos pelas florestas urbanas.

Uma quebra de paradigma é a valoração dos benefícios que as áreas verdes fornecem aos moradores próximos e seus usuários. O Novo Plano Diretor do município de São Paulo dá sinais de intensificação da verticalização e do adensamento em pontos estratégicos, nas proximidades do transporte público e do comércio regional. Como resposta, as áreas verdes e permeáveis sofrem pressão imobiliária para a conversão em novas unidades de negócio. É importante entender a complexidade de interesses dentro do espaço urbano, mas não se pode mais negligenciar o papel econômico e a importância social das árvores dentro deste espaço. 


\section{O VERDE EM SÃO PAULO}

De acordo com o Mapa de Vegetação do Brasil, (IBGE, 2004), a cidade de São Paulo está inserida no Domínio da Mata Atlântica. É um dos cinco mais importantes hotspots mundiais de biodiversidade (MYERS et al., 2000), da qual resta menos de $8 \%$ da cobertura original do bioma (FUNDAÇÃO SOS MATA ATLÂNTICA \& INPE, 2014). É considerado o mais ameaçado dos biomas florestais brasileiros, de acordo com a IUCN (2003).

Alguns trabalhos consideram que a região do município de São Paulo seria coberta por Florestas Subtropicais com Araucárias (HUECK, 1953), com a ocorrência de cerrado ou campos confinados a áreas com condições de solo particulares (AB'SÁBER 1963, 1970). Ou por Florestas Sempre Verdes relacionadas às Florestas Mistas Latifoliadas e de Araucárias (EITEN, 1970), ou ainda por uma transição entre a Floresta Ombrófila Densa Atlântica e a Floresta Estacional Semidecidual do interior do Estado de São Paulo (EITEN, 1970; ARAGAKI \& MANTOVANI, 1998).

Segundo USTERI (1911), a região onde se insere atualmente a cidade de São Paulo apresentava-se originalmente recoberta basicamente por vegetação de várzea, campos e florestas (SÃO PAULO, 2002).

A partir da década de 40, o perfil de São Paulo como metrópole industrial consolidouse definitivamente, iniciando-se o processo de periferização. Na década de 70 a concentração de renda intensificou-se e a lógica da construção da cidade passa pelo deslocamento das centralidades associado à exclusão territorial dos mais pobres, incrementando-se a favelização (SÃO PAULO, 2002).

A partir da década de 80 foram publicadas informações sobre a flora (MELHEM et al. 1981, BAITELLO \& AGUIAR 1982, PASTORE et al. 1992, ROSSI 1994, GARCIA 1995, GANDOLFI et al. 1995) e a estrutura do componente arbóreo-arbustivo dos fragmentos florestais atualmente existentes no Planalto Paulistano (DE VUONO 1985, GANDOLFI 1991, NASTRI et al. 1992, GOMES 1992, BAITELLO et al. 1992, GORRESIO-ROIZMAN 1993, ARAGAKI \& MANTOVANI 1994, TABARELLI 1994, KNOBEL 1995, TOMASULO 1995) (apud DISLICH et al, 2001).

Em 2002, o Atlas Ambiental do Município de São Paulo apresentou o mapeamento a partir de imagem de satélite Landsat do ano 2000 para a análise da expansão da urbanização e da fragmentação da vegetação. Foram mapeados 152.676,2 hectares 
dentro dos limites do município, sendo que, deste total $86.164,3$ hectares pertencem a classe zona urbana e $62.357,7$ hectares, a classe vegetação. Dentro da classe vegetação 11.521,3 ha são referentes a Parques e Bosques Urbanos, 50.836,4 ha referentes à Zona Rural, incluindo fragmentos de Mata Atlântica dentro de Unidades de Conservação, Reflorestamento e Agricultura. Portanto, o verde na área urbana de São Paulo se reduz a 7,54\% do total mapeado.

A flora da capital paulista tem uma diversidade considerável. Nos últimos 100 anos, listaram-se aproximadamente 3.100 espécies vasculares (pteridófitas, gimnospermas e angiospermas), sendo $84 \%$ nativas no município, segundo os registros compilados pelo Herbário Municipal até outubro de 2012 (SÃO PAULO, 2012).

Os trabalhos realizados indicam a existência de diversidade florística e estrutural elevada entre e dentro dos trechos de floresta estudados. As análises sobre este conjunto de dados, porém, foram realizadas de maneira superficial, desconsiderando as variações nas características físicas do local, a heterogeneidade intrínseca da floresta e o esforço amostral empregado, apenas comparando as floras obtidas (GOMES 1992, ARAGAKI \& MANTOVANI, 1994).

\section{FLORESTAS URBANAS E LEGISLAÇÃO}

O termo "Urban Forest" (Floresta Urbana) foi cunhado em 1965 pelo prof. Erik Jorgensen da Universidade de Toronto, o qual o descrevia como um ramo especializado da silvicultura que tem como objetivo o cultivo e o manejo de árvores visando o seu potencial fisiológico, sociológico e econômico, além do bem-estar da sociedade urbana. Estas contribuições incluem o impacto positivo das relações fisiológicas em seu ambiente de plantio, bem como a sua utilidade recreativa e a valoração de seus serviços ecossistêmicos.

No Brasil, o termo "Urban Forest" foi traduzido inicialmente como "Arborização Urbana" para designar o conjunto da vegetação arbórea, presente nas cidades. A IUFRO (União Internacional de Organizações de Pesquisa Florestal) passou a adotar como tema "Arboriculture and Urban Forestry" (Arboricultura e Manejo de Florestas Urbanas) e organizou seminários sobre este assunto, intitulado "Árvores e Florestas para as Cidades" separando claramente estes componentes. 
Árvores isoladas ou mesmo em pequenos grupos são bastante distintas de florestas. Estão presentes em quase toda a malha urbana, incluindo áreas predominantemente edificadas; são cultivadas e mantidas como indivíduos; são planejadas para ocupar o espaço e são podadas de acordo com as características físicas do local. Por outro lado, as florestas nas cidades estão em áreas maiores e contínuas e constituem ecossistemas característicos, com o estabelecimento de relações especificas com o solo, água, nutrientes, a fauna e outros componentes ambientais. As relações, funções e benefícios para as comunidades antrópicas presentes também são especificas, como áreas de lazer, parques ou unidades de conservação (MAGALHÃES, 2006).

O Município de São Paulo, através da Secretaria do Verde e Meio Ambiente - SVMA, a Secretaria do Meio Ambiente do Estado de São Paulo, através da Companhia Ambiental do Estado de São Paulo - CETESB, e o Instituto Brasileiro do Meio Ambiente e dos Recursos Naturais Renováveis, através do Conselho Nacional do Meio Ambiente - CONAMA tem legislações complementares e específicas para a vegetação de porte arbóreo.

A Portaria n. ${ }^{\circ}$ 126/SMMA.G, de 5 de novembro de 2002, considera:

Artigo $2^{\circ}$ - maciço é o conjunto arbóreo cuja projeção das copas cubra o solo em mais de $40 \%$ (quarenta por cento) da sua superfície.

Artigo $11^{\circ}$ - em fitofisionomias florestais nativas, quando tecnicamente factível, será desprezada uma faixa de $10 \mathrm{~m}$ (dez metros) de largura ao longo de todo o perímetro do maciço, para se evitar a influência do efeito de borda na caracterização da estrutura. ao estágio sucessional.

A Decisão de Diretoria № 287/2013/V/C/l, de 11 de setembro de 2013, da CETESB, que dispõe sobre procedimentos para a autorização de supressão de exemplares arbóreos nativos isolados, define:

Artigo $2^{\circ}$ - Para efeito desta Decisão de Diretoria entende-se por: I - Exemplares arbóreos nativos isolados: aqueles situados fora de fisionomias vegetais nativas sejam florestais ou de Cerrado, cujas copas ou partes aéreas não estejam em contato entre si, destacando-se da paisagem como indivíduos isolados. 
A Resolução CONAMA n 01, de 31 de janeiro de 1994 considera os critérios para a definição de fragmentos florestais em estágios inicial, médio ou avançado de regeneração de Mata Atlântica. Os fragmentos passam por avaliação de fisionomia, estratos verticais, relação altura e diâmetro, presença de epífitas, trepadeiras, diversidade biológica, espécies abundantes e serapilheira.

Observando estes dispositivos, tem-se que, o limite entre um conjunto de árvores isoladas e o maciço arbóreo se dá pela projeção da copa das árvores. Também é necessário fazer uma diferenciação entre maciços arbóreos e fragmento florestal em estágio inicial de regeneração, através dos componentes verticais e na diversidade e riqueza de espécies nativas.

Têm-se, portanto a 'Arborização Urbana' composta por indivíduos arbóreos isolados e pequenos maciços arbóreos nativos ou exóticos, e 'Floresta Urbana' composta por grandes maciços arbóreos nativos ou exóticos e fragmentos de florestas nativas em diversos estágios de regeneração.

Estruturalmente, as Florestas Urbanas seriam compostas pelo conjunto, muitas vezes heterogêneo, de manchas, corredores e matrizes vegetadas, distribuídas nas mais diversas formas e padrões, no interior dos aglomerados urbanos e a eles circundantes. Seu papel é estratégico para a manutenção de conectividades desejáveis entre espécies na paisagem e na mitigação de impactos ambientais, observadas a funcionalidade e o grau de modificação ao longo do tempo (PELLEGRINO, 2000).

A Lei Federal $n^{\circ} 12.651$, de 25 de Maio de 2012, que institui o Código Florestal, alterada pela Lei Federal $n^{\circ} 12.727$, de 17 de outubro de 2012, define em seu Artigo $3^{\circ}$ as Áreas de Preservação Permanente - APP:

"área protegida, coberta ou não por vegetação nativa, com a função ambiental de preservar os recursos hídricos, a paisagem, a estabilidade geológica e a biodiversidade, facilitar o fluxo gênico de fauna e flora, proteger o solo e assegurar o bem-estar das populações humanas as áreas de preservação permanente".

AAPP, quando vegetada exerce o papel de corredor para a fauna e flora e pode transformar os ambientes urbanos em áreas de convívio e lazer. Os remanescentes de porte arbóreo que formam o mosaico de Floresta Urbana podem ser conectados por 
áreas de preservação permanente - APP, protegidas por Lei, formando um corredor verde dentro da cidade de São Paulo.

\section{TRILHA NORTE SUL, CORREDOR VERDE E ECOLOGIA DA PAISAGEM}

A Trilha Norte-Sul é um estudo proposto pela disciplina AUP5853 - Desenho Ambiental da Faculdade de Arquitetura e Urbanismo de São Paulo, ministrada por Maria de Assunção Ribeiro Franco. O estudo definiu um percurso que corta São Paulo desde o Parque Estadual da Serra da Cantareira, na Zona Norte até o parque Alfredo Volpi, no Morumbi, Zona Sul, com uma extensão de aproximadamente de 20 quilômetros e uma largura de 7 quilômetros, passando por importantes áreas verdes de São Paulo, como o Horto Florestal, e os parques Água Branca, Ibirapuera, Mario Pimenta Camargo (Parque do Povo), e por importantes bacias hidrográficas, como a dos córregos do Bispo, Sapateiro, Água branca e Mandaqui. A importância da microbacia do Ribeirão do Mandaqui chama a atenção para a publicação deste estudo.

Em 2010, Franco propõe um Corredor Verde entre os parques Ibirapuera-Villa Lobos com foco na conectividade entre espaços naturais, os parques e outros espaços abertos através da Infraestrutura verde.

No Planejamento e no Desenho Ambiental, a Infraestrutura Verde pode ser entendida como uma rede interconectada de áreas verdes naturais e outros espaços abertos que conservam valores e funções ecológicas, sustentam ar e água limpos e ampla variedade de benefícios para as pessoas e a vida selvagem de deverão nortear as ações de planejamento e desenvolvimento territoriais que deve garantir a existência dos processos vivos no presente e no futuro (FRANCO,2010).

A diferença intencional entre corredor verde e corredor ecológico está complexidade do ambiente urbano em promover nas mesmas circunstâncias de um ambiente florestal natural, a interação sinérgica entre a estrutura vertical e horizontal.

Enquanto o corredor verde contém o planejamento de mobilidade, transporte público, mobiliário urbano e Arborização Urbana, entre outros, o corredor ecológico precisa da complexidade das Florestas Urbanas e de áreas verdes naturais para existir.

Os corredores verdes ganham força ao formarem redes de mobilidade segura, dando 
prevalência ao pedestre e aos meios de transporte movidos a energia não poluente, recuperando a memória de antigos caminhos e trilhas e incorporando o valor paisagístico dos percursos e sítios notáveis. Aí entra em cena de forma contundente a idéia da liberação da dependência do automóvel, o uso da bicicleta e o andar a pé (FRANCO, 2010).

Arruda (2000) afirma que a Conservação da Biodiversidade pode ser feita em várias escalas, dependendo da abordagem adotada. Neste contexto, o termo corredor ecológico urbano busca se consolidar como um conjunto de ações no âmbito da restauração para integrar os fragmentos de Floresta Urbana às Unidades de Conservação no município a partir da recuperação das APPs do Ribeirão do Mandaqui.

A ecologia de paisagens é o estudo da estrutura, função e dinâmica de áreas heterogêneas compostas por ecossistemas interativos (Forman \& Godron 1986); a investigação da estrutura e funcionamento de ecossistemas na escala da paisagem (Pojar et al. 1994); uma área de conhecimento que dá ênfase às escalas espaciais amplas e aos efeitos ecológicos do padrão de distribuição espacial dos ecossistemas (Turner 1989); uma forma de considerar a heterogeneidade ambiental em termos espacialmente explícitos (Wiens et al. 1993); uma área de conhecimento que considera o desenvolvimento e a dinâmica da heterogeneidade espacial, as interações e trocas espaciais e temporais através de paisagens heterogêneas, as influências da heterogeneidade espacial nos processos bióticos e abióticos e o manejo da heterogeneidade espacial (Risser et al. 1984); uma ciência interdisciplinar que lida com as interações entre a sociedade humana e seu espaço de vida, natural e construído (Naveh \& Lieberman 1994), segundo Jean Paul Metzger (2001).

Essas definições mostram uma nítida bifurcação no foco principal de interesse do ecólogo da paisagem. De um lado, há uma ecologia humana de paisagens, centrada nas interações do homem com seu ambiente, onde a paisagem é vista como o fruto da interação da sociedade com a natureza. Essa é a linha seguida pela "abordagem geográfica". De outro lado, há uma ecologia espacial de paisagens, particularmente preocupada na compreensão das consequências do padrão espacial (forma pela qual a heterogeneidade se expressa espacialmente) nos processos ecológicos. Esta é a linha principal de pesquisa na "abordagem ecológica".

Metzer (2006) diz que o ponto central da análise em ecologia de paisagens é o reconhecimento da existência de uma dependência espacial entre as unidades da paisagem: o funcionamento de uma unidade depende das interações que ela mantém 
com as unidades vizinhas (diferentes tipos de habitats). A ecologia de paisagens seria assim uma combinação de uma análise espacial da geografia com um estudo funcional da ecologia. A problemática central é o efeito da estrutura da paisagem (padrão espacial) nos processos ecológicos.

Busca-se, portanto, inspirada nas propostas apresentadas por profissionais e estudantes para a Trilha Norte Sul de São Paulo, uma integralização dos processos ecológicos dentro do ambiente urbano através da restauração florestal, como forma de interligar áreas existes e criar novas áreas de Florestas Urbanas. Estas florestas poderão ser valoradas através da Prestação de Serviços Ecossistêmicos intrínsecos à sua existência compor uma rede de parques e áreas verdes formando um corredor ecológico urbano.

\section{RESTAURAÇÃO FLORESTAL}

Uma floresta, para desempenhar um serviço ambiental necessita de condições de desenvolvimento saudável orientando-a para o estado de floresta clímax - um ecossistema no qual as comunidades encontram-se em equilíbrio, por meio dos processos de sucessão ecológica (BALÉE, 1989).

Para tanto é necessário o estabelecimento do ciclo de carbono e nutrientes, que equilibra a relação entre o solo e a vegetação, gerando matéria orgânica. Parte da matéria orgânica no solo, devido à ação de agentes decompositores é transformada em substâncias húmicas, que são importantes para a prestação de serviços ecossistêmicos relacionados com o ciclo de carbono. Essas substâncias representam o estoque definitivo de carbono no solo - estima-se que o montante sequestrado chega a mais de quatro vezes o volume estocado em biomassa aérea no planeta (AMARAL, 2015).

A Figura 3 ilustra a abordagem feita por Hobbs e Norton (1996) e Hobbs e Harris (2001) a respeito dos estados dos ecossistemas e a transição entre ambientes intactos para degradados. Os estados são indicados em caixas, e as possíveis transições são representadas por flechas. Os limiares ecológicos que definem a passagem de um estado menos degradado a um mais degradado estão indicados pelas barras sombreadas verticais. 


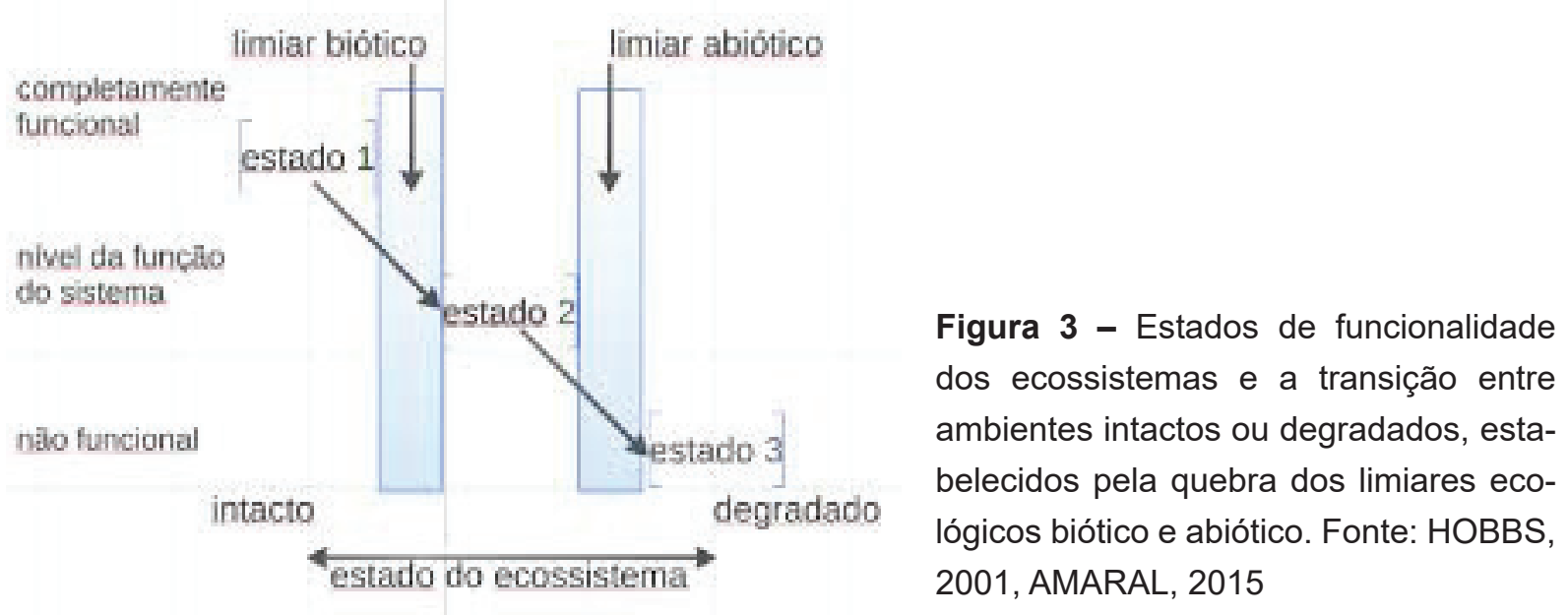

Aqui se apresentam os dois principais limiares existentes entre sistemas degradados e preservados ou intactos $\mathrm{O}$ primeiro limiar refere-se a perdas bióticas e, geralmente, envolve comprometimento irreversível de elos bióticos e de suas respectivas resiliências (perda de espécies ou de elos microbianos dos ciclos biogeoquímicos).

Nesse quadro, referente ao estado 1 , os procedimentos de recuperação são denominados restauração ou enriquecimento. $\mathrm{O}$ cruzamento do segundo limiar - o abiótico - refere-se ao estado 3. Caracterizado pela ausência de resiliência, pode resultar em um processo final de desertificação, caso não haja intervenção antrópica. O procedimento de recuperação é denominado reabilitação. Demanda, normalmente, modificação física para se direcionar os sistemas a um novo nível de estabilidade e pode ser associado a mellhorias implementadas pelo estabelecimento de uma nova função. Entre os dois limiares - estado 2 - o ecossistema requer ações como a reintrodução de espécies, entretanto não é preciso intervir no meio físico. Nesse caso, o procedimento de recuperação é conhecido como revegetação ou reflorestamento (HOBBS e HARRYS, 2001; AMARAL, 2015).

Com a observação dos limiares ecológicos rompidos pelo sítio, a Ecologia da Restauração estabelece que se adotem metas objetivas de recuperação ecológica, que permitam, sobretudo o monitoramento do sucesso das intervenções escolhidas. Isso é importante, dada a complexidade de fatores envolvendo esse processo, sendo o realinhamento de ações, por vezes necessário.

Há o entendimento de que, quando o limiar abiótico já foi há muito ultrapassado - 
caso da maioria dos sítios urbanos - pode-se utilizar, alternativamente, um sistema próximo como modelo funcional a fim de se aferir as prováveis intervenções a serem adotadas. Assim é possível estabelecer as metas de restauração, não embasados no que a área sob estudo foi, mas no que se deseja que ela venha a se tornar.

A relevância do tema desta pesquisa se dá pelo significativo papel que as florestas urbanas podem exercer na prestação de serviços ecossistêmicos relacionados ao ciclo de carbono, com a possibilidade de introdução no meio urbano de áreas orientadas para a melhoria da qualidade de vida nas cidades.

\section{SERVIÇOS ECOSSISTÊMICOS E SEQUESTRO DE CARBONO}

O sequestro de carbono $(C)$ em biomassa aérea e pelo solo é um dos principais serviços ecossistêmicos florestais, cujo entendimento propicia a instrumentalização do aumento de absorção biológica de carbono preconizada pelo IPCC.

Outro significativo serviço ecossistêmico florestal é a drenagem natural dos solos. Esse serviço ambiental decorre da plena instalação do ciclo biogeoquímico de carbono e é associado à manutenção dos aquíferos e das bacias hidrográficas. A impermeabilização do solo, com a supressão de manchas florestais, em aglomerados urbanos, compromete a disponibilidade superficial de água doce no planeta (BALÉE, 1989; BROWN, 2003; BONAM, 2008; LOVELL; TAYLOR, 2013, apud AMARAL, 2015).

A produção de matéria humificada impacta positivamente a geração de nutrientes necessários para suporte ao desenvolvimento da vegetação, auxilia o sequestro de carbono em biomassa aérea, bem como o desempenho fotossintético das plantas; gera condições de estoque de $\mathrm{C}$ no solo pela melhoria de sua aeração e porosidade, atributos por sua vez relacionados com a drenagem necessária para a manutenção de aquíferos e corpos d'água. Esses serviços ecossistêmicos podem ainda ser interrelacionados a outros, como melhoria microclimática, conservação da biodiversidade, fertilidade do solo e produção de alimentos (BONAM, 2008; TREVISAN et al., 2010; RONQUIN, 2010; WICK; INGRAM; STAHL, 2010; LOVELL; TAYLOR, 2013; LAL, 2004; AMARAL, 2012 apud AMARAL, 2015).

Enfocando a possibilidade de introdução desses serviços em meio urbano, a fim de alinhar o desenho e o planejamento das cidades à estratégia global de aumento da 
absorção biológica de carbono, torna-se necessário a compreensão do papel das florestas urbanas nesses processos.

A possibilidade de prestação de serviços ecossistêmicos urbanos agregam os de natureza recreativa, educativa e estética, relacionados ao potencial de interação cultural desses espaços com as populações urbanas. Tem-se como exemplo o bem estar psicológico causado pela presença da vegetação nas vizinhanças e a crescente utilização de áreas de parque no Brasil para a realização de atividades de lazer (LOVELL; TAYLOR, 2013).

Relaciona-se ainda uma gama de outros serviços ecossistêmicos de natureza biológica, mas que, decorrentes da interação da floresta urbana com as cidades, podem ser caracterizados como urbanos. Falam-se assim de benefícios como a absorção de poluentes e partículas, a prevenção e redução da erosão do solo, a purificação da água, o alívio da poluição sonora.

\section{VALORAÇÃO E PAGAMENTO POR SERVIÇOS AMBIENTAL}

De acordo com a Secretaria Municipal de Coordenação das Subprefeituras - SMSP, a cidade de São Paulo possui pouco mais de 640 mil árvores espalhadas pelos seus 96 distritos, o que equivale a uma média de 425,5 árvores por quilômetro quadrado.

Dentre os dez distritos mais arborizados de São Paulo, oito deles também estão na lista dos distritos com metro quadrado mais caro da cidade (em ordem decrescente de valor): Alto de Pinheiros, Pinheiros, Jardim Paulista, Campo Belo, Itaim Bibi, Moema, Vila Mariana e Consolação, de acordo com a matéria da Revista EXAME, por Yazbek (2016).

O distrito de Moema é o mais valorizado de São Paulo, segundo o Properati, tem valor médio de metro quadrado de 12.782 reais e está em oitavo lugar na lista dos mais arborizados, com 1,26 mil árvores por quilômetros quadrados. O Mandaqui está na posição 70 do ranking de arborização e o valor médio do metros quadrado é de 5.785 reais.

Isto mostra a importância da arborização e da proximidade com parques urbanos na valoração dos terrenos na compra e venda. Tendo como foco a estrutura da paisagem, a mudança de paradigma e a adoção de novas áreas vegetadas através da restauração florestal, propõe-se um novo cenário para São Paulo através do estudo de caso da microbacia do Ribeirão do Mandaqui. 
Alguns projetos de Lei como a LEI No 792; LEI № 1.190, ambas de 2007, e da LEI N. ${ }^{\circ}$ 5.487, DE 2009 estão tramitando a passos lentos e podem ser um grande avanço para a compensação financeira daqueles que, de forma voluntária, se esforçam na manutenção ou na ampliação das condições ambientais adequadas para a vida na Terra.

As propostas de lei representam uma resposta aos estudos apresentados pelo Painel Intergovernamental de Mudanças Climáticas - IPCC e nos acordos firmados nas conferencias do clima - COP.

\section{ESTUDO DE CASO: RIBEIRÃO DO MANDAQUI}

Cabral (2015) relata em um texto quase poético que, ao se caminhar pela Avenida Engenheiro Caetano Álvares, na Zona Norte de São Paulo é praticamente inacessível à consciência que, abaixo da superfície, há diversos córregos menores que desaguam no Mandaqui. A Figura 4 a seguir apresenta a localização da área de estudo dentro do município de São Paulo.

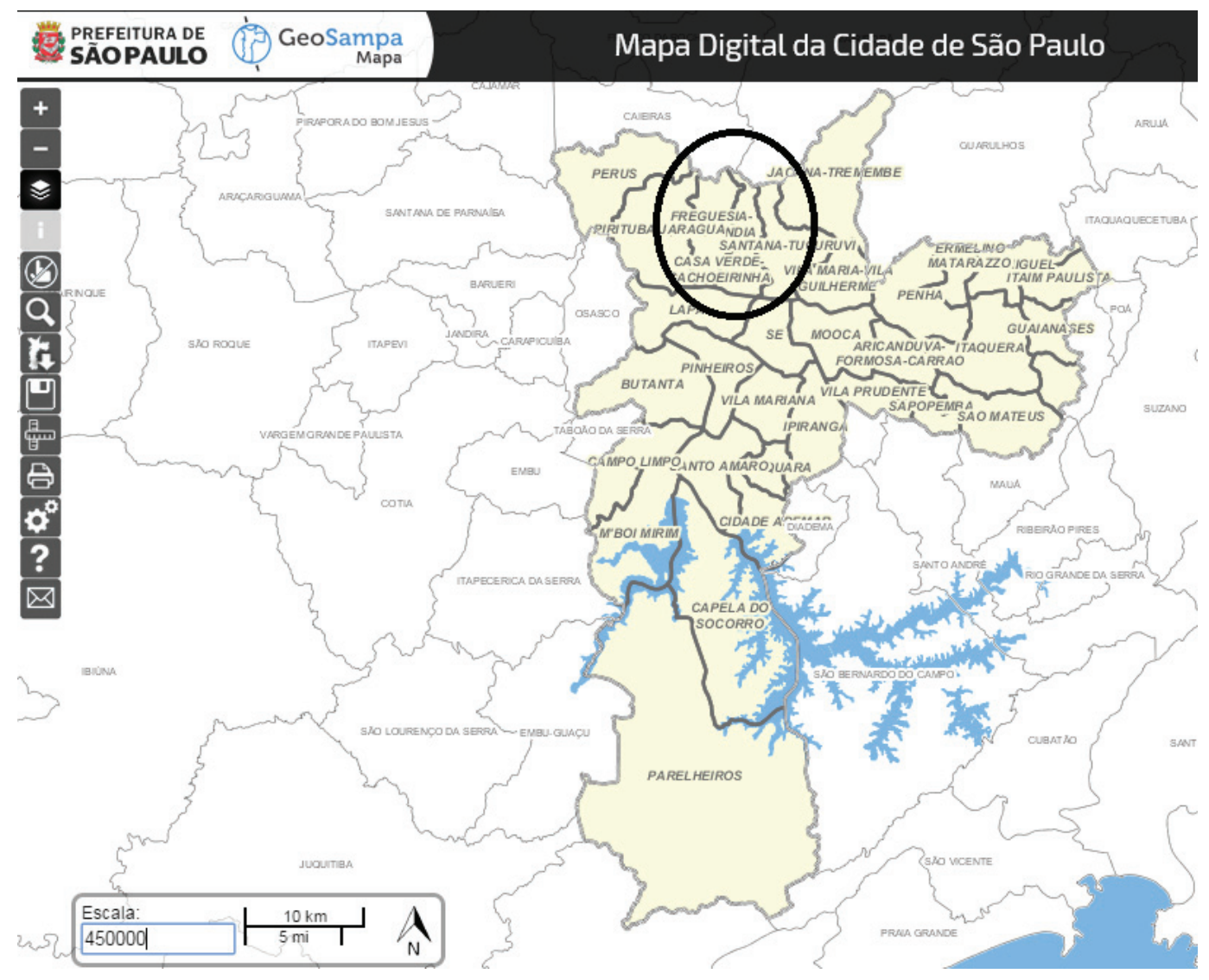

Figura 4 - Localização da área de estudo na Zona Norte de São Paulo, distritos do Mandaqui e da Casa Verde. Fonte: Geosampa em 23/05/16 
O Ribeirão ou Córrego do Mandaqui nasce nas encostas próximas ao Horto Florestal e à Invernada da Policia Militar, no extremo norte de São Paulo, ao pé da Serra da Cantareira. A Figura 5 apresenta as cabeceiras do Ribeirão do Mandaqui sob carta topográfica do SARA, de 1930. E a Figura 6 apresenta a microbacia do Ribeirão do Mandaqui como um todo.

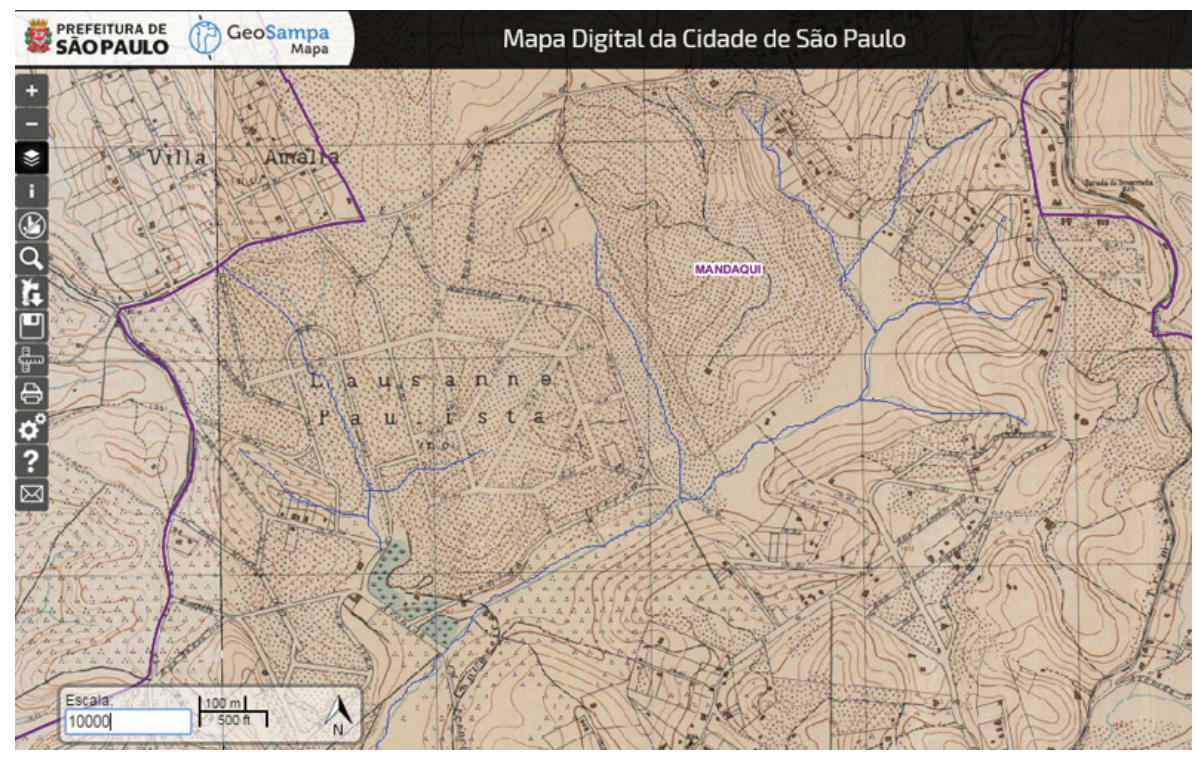

Figura 5 - Cabeceiras do Ribeirão do Mandaqui sob carta topográfica do SARA, de 1930. Fonte: Geosampa em 23/05/16

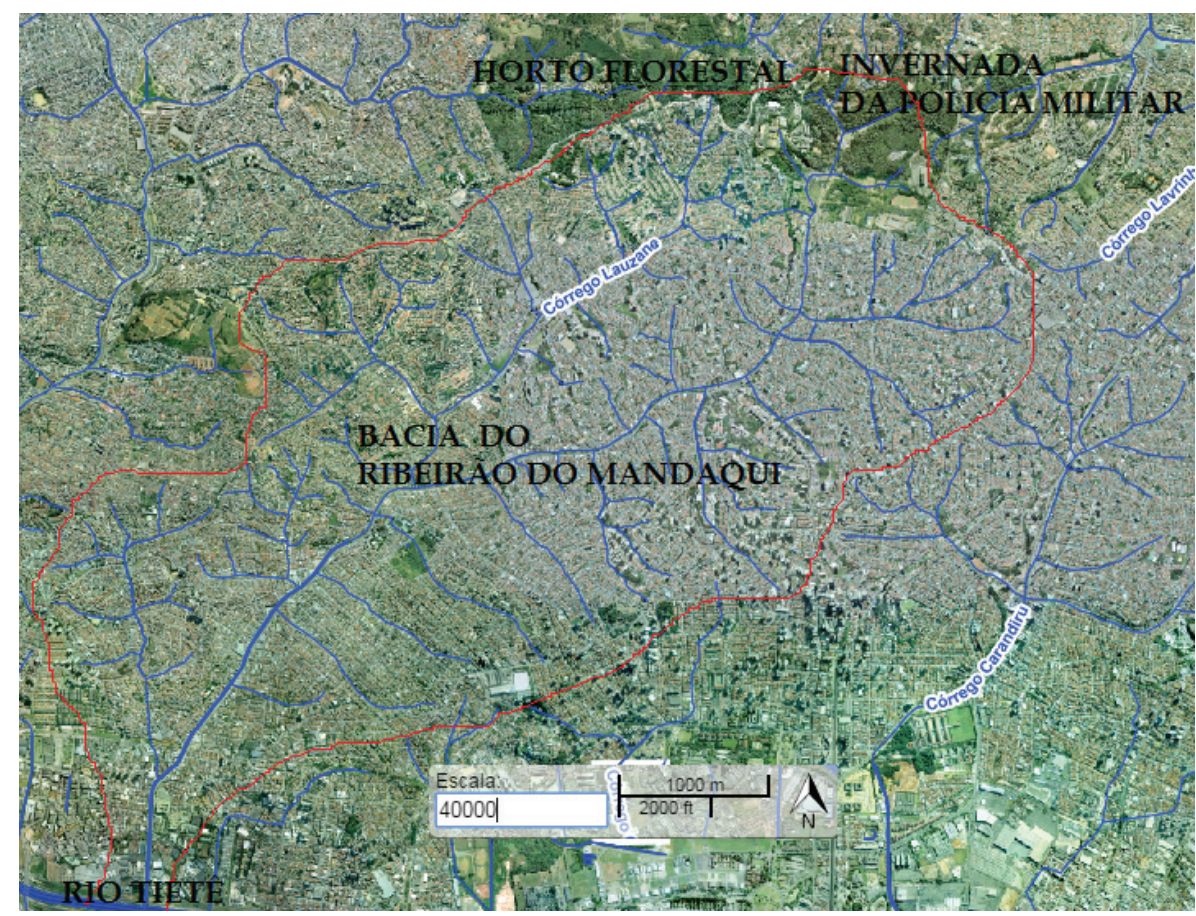

Figura 6 - Em destaque a localização da Bacia do Ribeirão do Mandaqui. Fonte: Geosampa em 23/05/16. 


\section{HISTÓRICO DE OCUPAÇÃO}

A colonização da zona norte do município de São Paulo tem a primeira referência no ano de 1616, quando a Câmara da então Vila de São Paulo de Piratininga deu permissão ao bandeirante Amador Bueno da Ribeira para construir um moinho de trigo ao lado do Ribeirão Mandaqui que era afluente da margem direita do Rio Grande (atual Tietê) (PONCIANO, 2001).

O mais antigo núcleo de povoamento situado na zona norte da capital é o de Santana. Tem sua origem em 1673 com a doação de uma sesmaria do Colégio da Companhia de Jesus. Em seu primeiro momento seria uma zona despovoada e sem recursos, um longínquo bairro rural cujo elemento mais importante seria a fazenda dos jesuítas. A extensa várzea do Tietê formava uma faixa de separação entre a área urbanizada, centro até região da Luz, e a área rural, onde se encontrava a fazenda de Santana.

No final do século a economia do café transforma a cidade provincial em metrópole e com a política imigratória parte das terras da Fazenda Santana foi loteada, em 1877, para a criação de núcleos coloniais, constituindo oferta de terrenos a baixo custo em localização "longínqua" da cidade. A implantação do Tramway da Cantareira, com inicio em 1893, contribuiu com a melhoria do acesso à região e em consequência, a população começou a se amontoar em lotes baratos com casas modestas, ruas mal planejadas e sem arborização. A área originalmente denominada Distrito de Santana deu origem a inúmeros outros bairros, como Mandaqui, Tucuruvi, Casa Verde, Cachoeirinha, Tremembé e Jaçanã. (BONDAR e HANNES, 2014).

A Figura 7, Figura 8 e Figura 9 a seguir foram retiradas dos sites São Paulo Antiga e Gazeta ZN e mostram os resquícios de vegetação em lotes vazios e a arborização urbana recente no bairro.

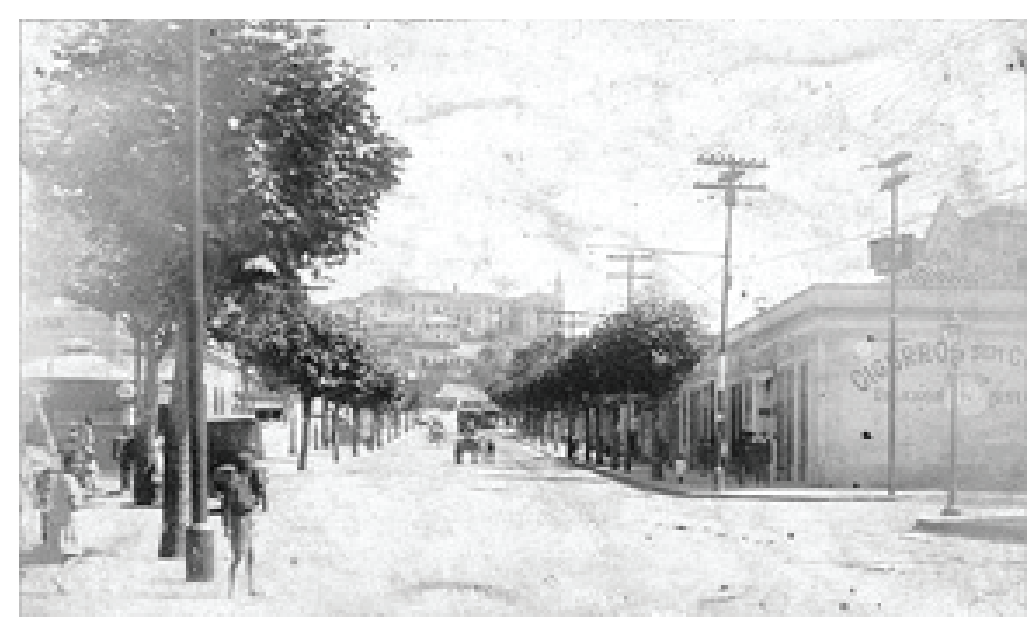

Figura 7 - Rua Voluntários da Pátria na década de 30 . Fonte: A Gazeta da Zona Norte 

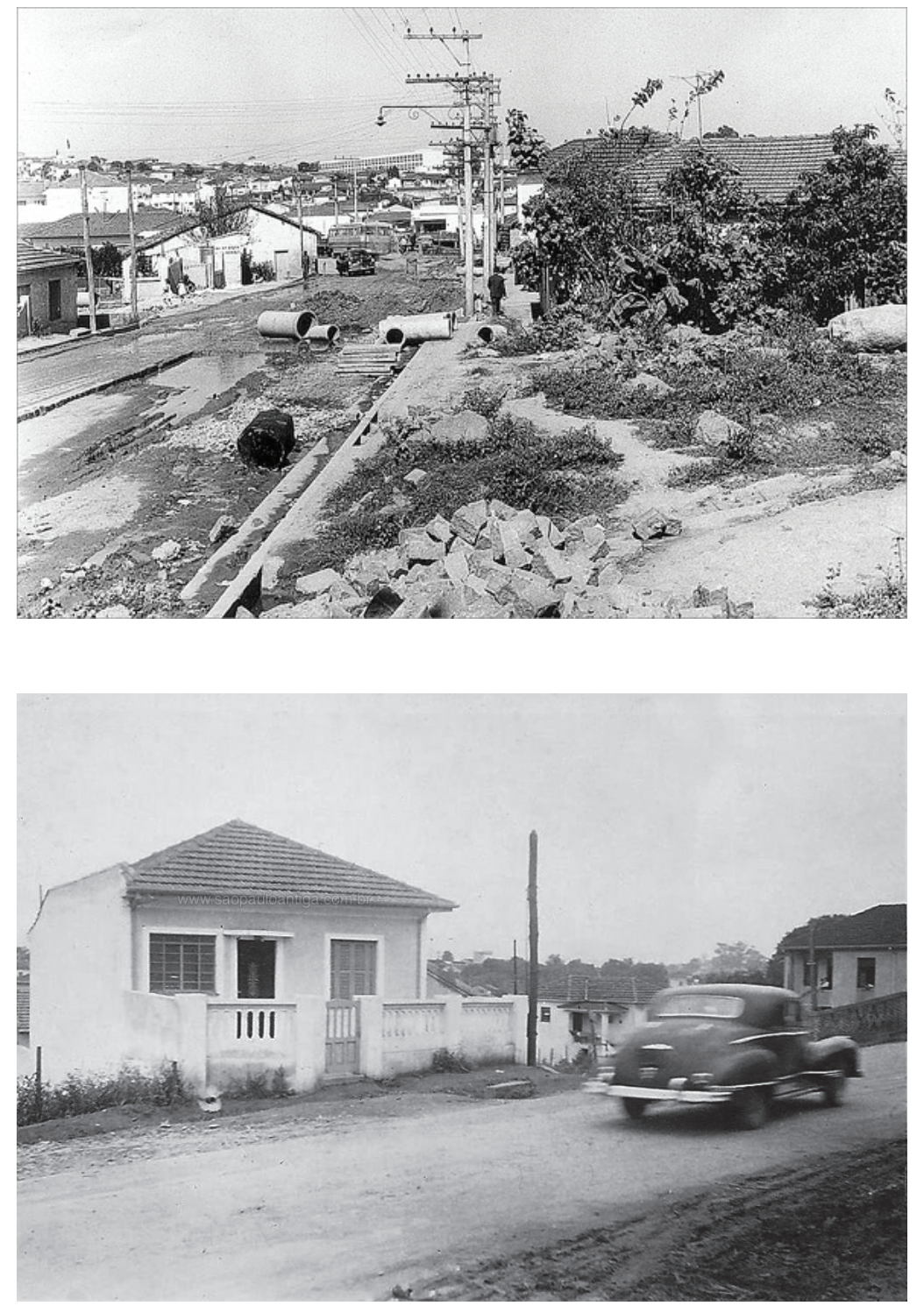

Figura 8 - Avenida Imirim na década de 70 .

Fonte: A Gazeta da Zona Norte

Figura 9 - Avenida Casa Verde década de 40.

Fonte: São Paulo Antiga

\section{METODOLOGIA}

Por meio de pesquisa exploratória, com coleta de dados bibliográfica e documental sobre paisagem, morfologia urbana, ecologia da restauração, serviços ecossistêmicos - florestais e urbanos e sequestro de carbono em ecossistemas terrestres, foi possível delimitar o universo de pesquisa e contextualizar o tema do trabalho.

Utilizou-se os dados disponibilizados pela prefeitura de São Paulo através da plataforma digital GeoSampa, e o Google Earth para a edição de mapas, imagens e figuras.

Ao longo do deslocamento entre a Serra da Cantareira até a Várzea do Rio Tietê, 
preocupou-se em observar os aspectos físicos, sociais e paisagísticos. Muitas leituras podem ser feitas neste contexto urbano da Avenida Caetano Álvares, no leito do Ribeirão Mandaqui, com o intuito de melhorar o bem estar da população que convive com este espaço urbano.

A vistoria de reconhecimento de campo foi realizada no dia 21 de março de 2016 e no dia 02 de maio de 2016 tem como objetivo relatar as percepções dos seguintes trechos: 1- Horto Florestal / Pedra Grande (Serra da Cantareira), 2 - Rua Voluntários da Pátria, 3 - Avenida Imirim, 4 - Avenida Casa Verde.

Estes trechos cortam transversalmente a Avenida $\mathrm{Eng}^{\circ}$ Caetano Álvares, situada num fundo de vale, onde o Ribeirão Mandaqui foi canalizado e tem parte do seu percurso coberto. Os transeptos possuem aproximadamente um quilômetro de extensão.

Foram avaliados nos transeptos a percepção do espaço urbano e seu uso, a percepção climática relacionada ao bem estar e a percepção visual da cobertura vegetal em áreas verdes, canteiros, áreas particulares, praças e parques ao longo do Ribeirão do Mandaqui.

A Figura 10 apresenta a localização dos transeptos ao longo do Ribeirão do Mandaqui, sob a Avenida Engenheiro Caetano Álvares.

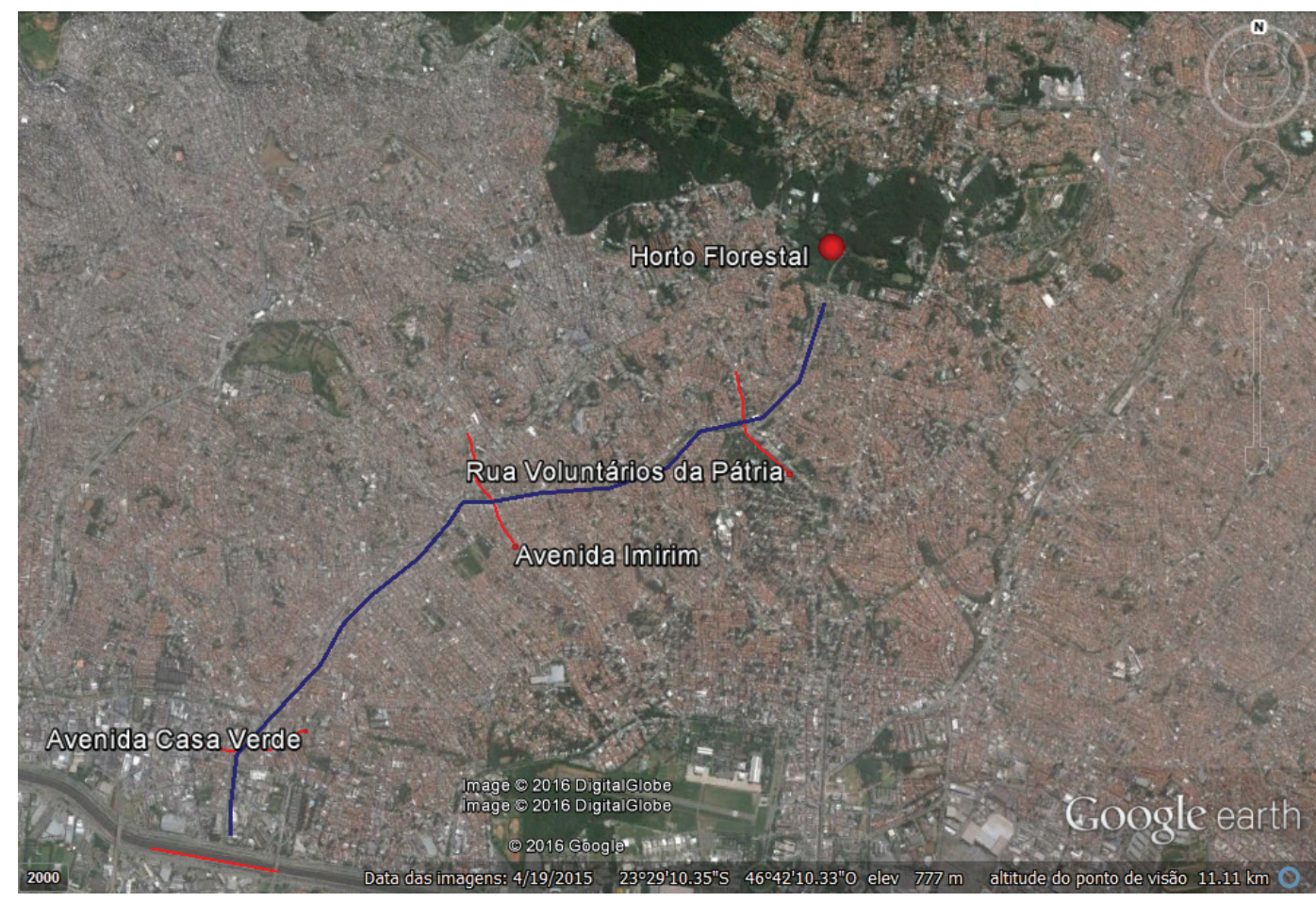

Figura 10 - Localização dos transeptos ao longo do Ribeirão do Mandaqui. Fonte: Google Earth. Acesso em 23/05/16 


\section{GEOMORFOLOGIA, RELEVO DO SOLO E HIDROGRAFIA}

A área de estudo é formada, na maior parte de sua extensão, por um maciço granítico originário de unidades magmáticas e metamórficas de embasamento pré-cambriano (alto da Serra da Cantareira). As planícies aluviais do Tietê são originárias do quartenário e composta por argilas e areias (Ab'Saber,2007), conforme Figura 11.

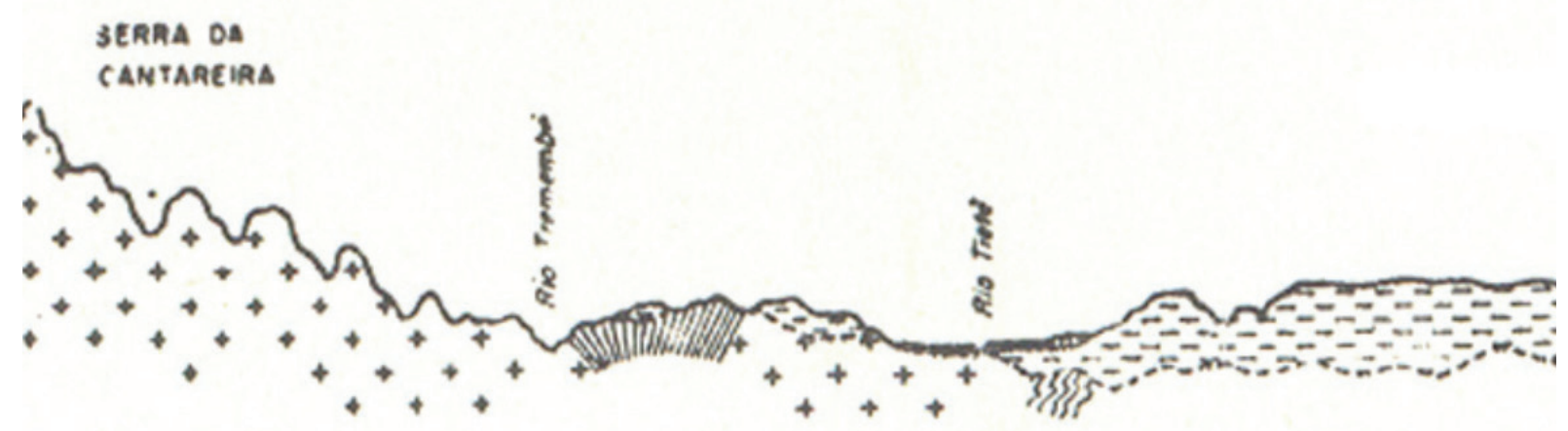

Figura 11 - Seção geológica da Serra da Cantareira. Fonte: Aziz Ab'Saber, Geomorfologia do sítio urbano de São Paulo.

O relevo do alto da Serra da Cantareira até a Rua Voluntários da Pátria varia entre fortemente ondulado a ondulado. A partir do cruzamento com a Avenida Caetano Álvares, o relevo se apresenta suavemente ondulado.

Os transeptos que cortam transversalmente a Avenida Eng ${ }^{\circ}$ Caetano Álvares, onde o Ribeirão Mandaqui foi canalizado e tem parte do seu percurso tamponado e as percepções quanto a variação do relevo em cada transepto são apresentadas na Figura 12, Figura 13 e Figura 14 a seguir.

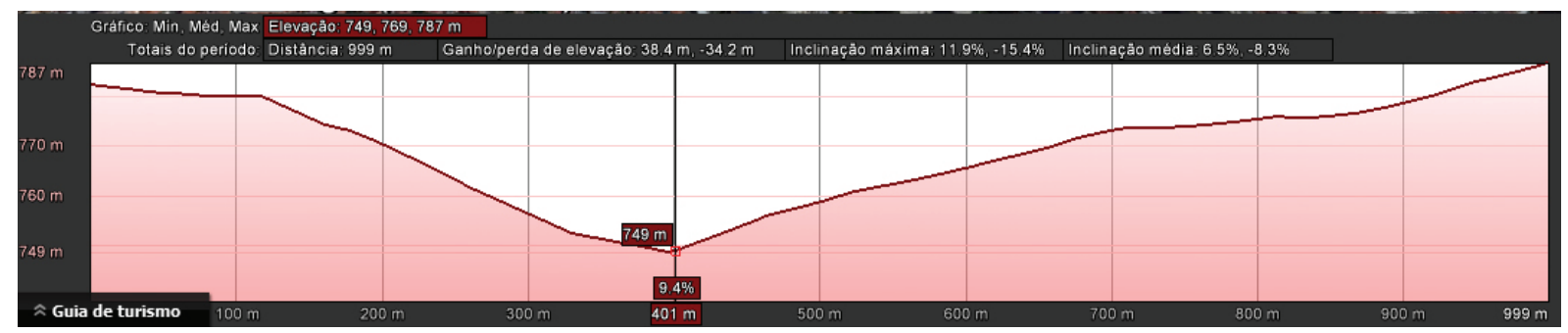

Figura 12 - Perfil de elevação do transepto da Rua Voluntários da Pátria. Fonte: Google Earth. Acesso em 23/05/16 


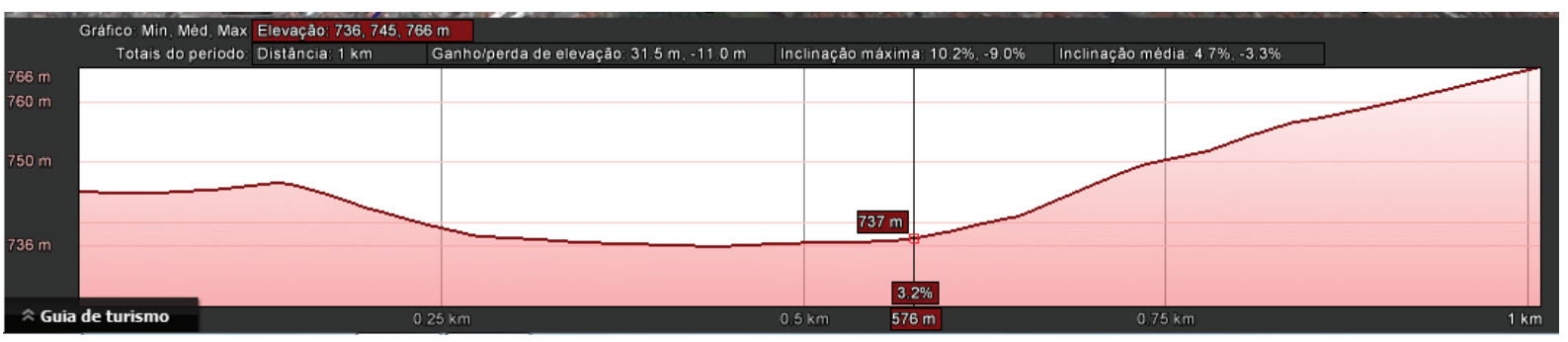

Figura 13 - Perfil de elevação do transepto da Avenida Imirim. Fonte: Google Earth. Acesso em 23/05/16.

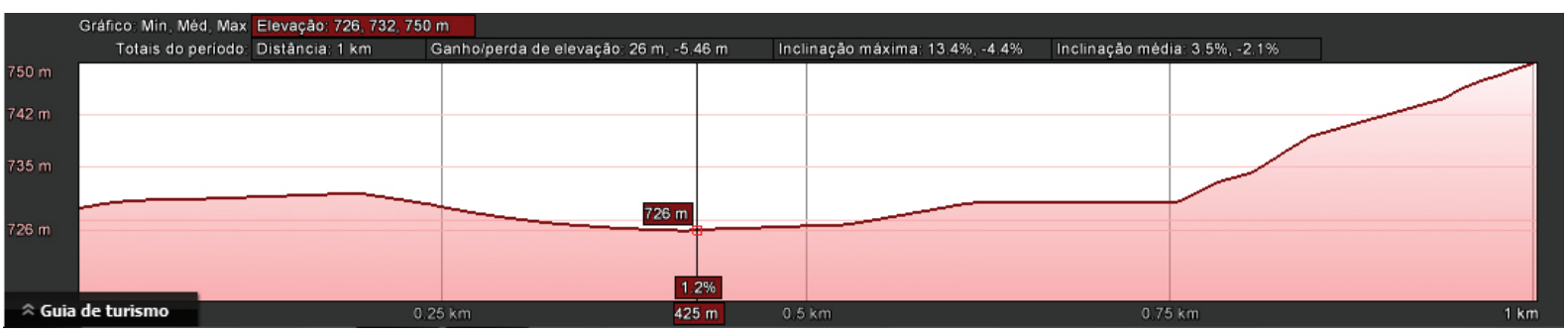

Figura 14 - Perfil de elevação do transepto da Avenida Casa Verde. Fonte: Google Earth. Acesso em 23/05/16

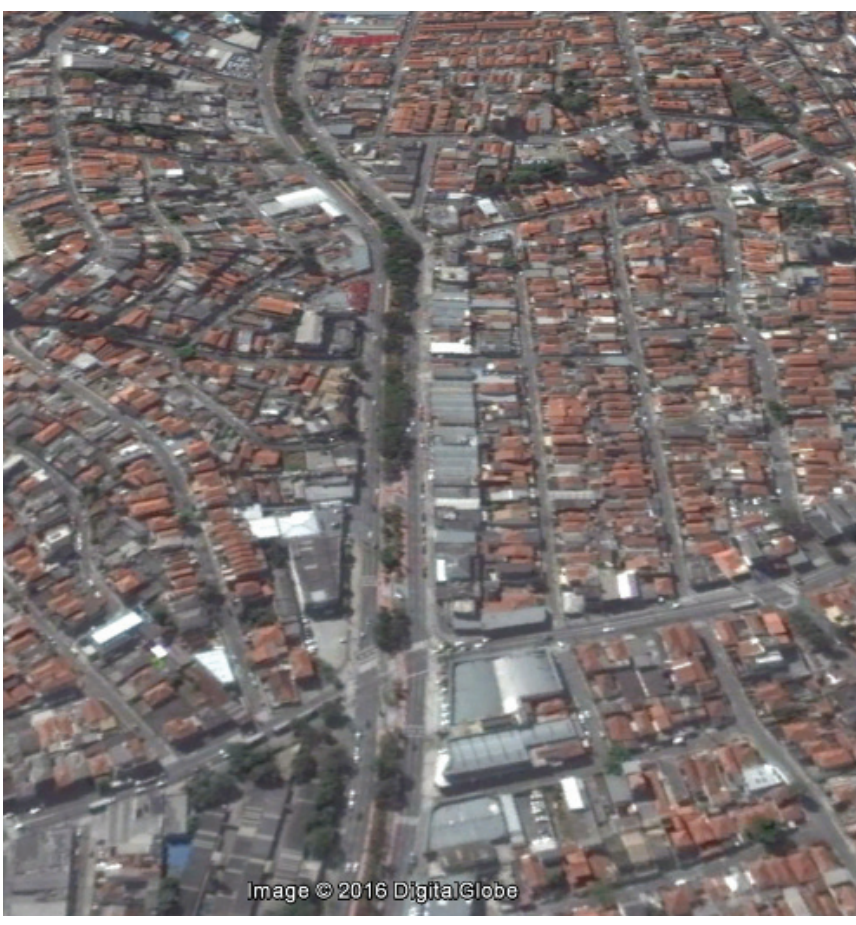

Figura 15 - Avenida Caetano Álvares no cruzamento com a Av. Imirim, na zona Norte de São Paulo. Detalhe para o Ribeirão do Mandaqui, canalizado e tamponado Fonte: Google Earth. Acesso em 23/05/16
No trecho onde o rio foi canalizado e tamponado foram feitas obras para ordenar o fluxo de automóveis. O local apresenta arborização em um canteiro central (Figura 15). Nos trechos mais largos existem praças com bancos e ciclovia e nos trechos mais estreitos, há um canteiro central com ciclofaixa ao longo da avenida.

O Ribeirão do Mandaqui segue canalizado e tamponado até a altura da Rua Orense, no Imirim (Figura 16). Em torno do seu eixo, o relevo suave conduz as águas até o encontro com o Rio Tietê, na Casa Verde. 


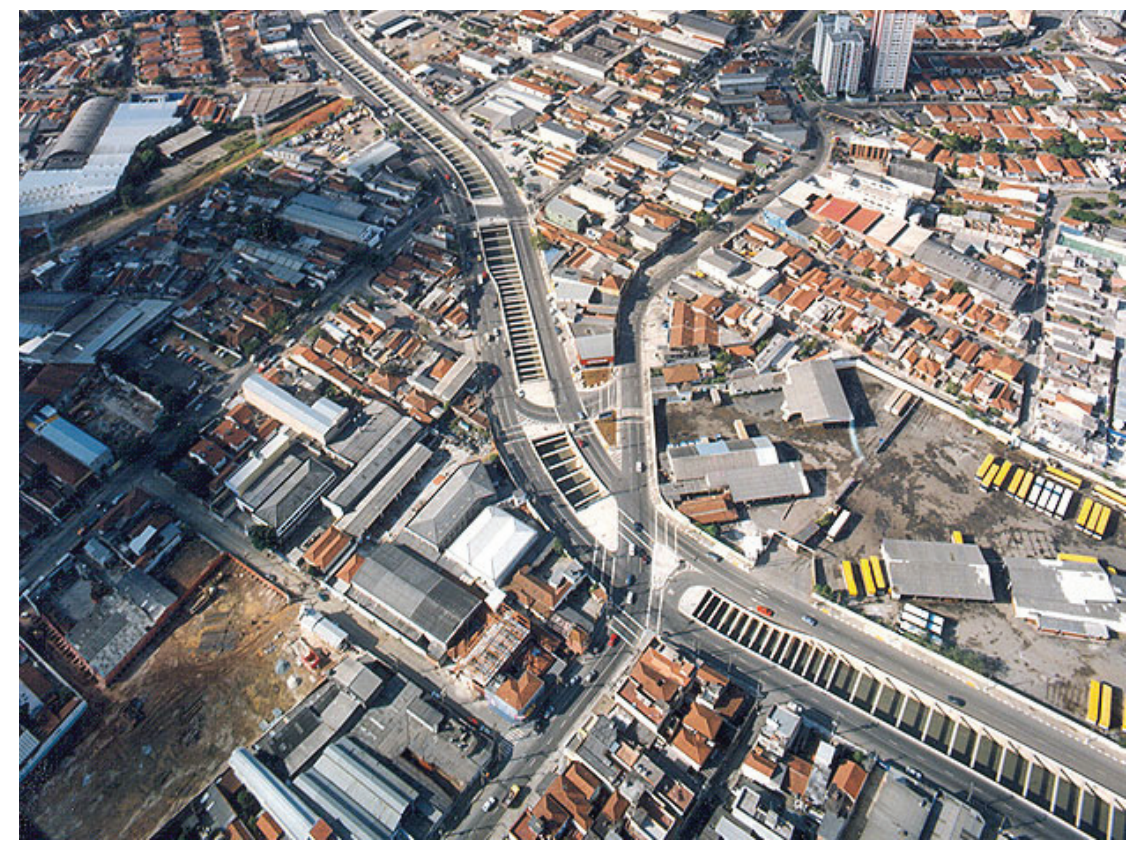

Figura 16 - Avenida Caetano Álvares no cruzamento com a Av. Casa Verde, na zona Norte de São Paulo. Detalhe para o Ribeirão do Mandaqui, canalizado. Fonte: Construbase. Acesso em 23/05/2015

\section{RESULTADOS}

\section{Percepção do Espaço Urbano}

Trecho 2: Rua Voluntários da Pátria

Neste trecho, observa-se uma predominância de residências com padrão médio/alto e no sentido de Santana há edifícios de múltiplos pavimentos. Há um comércio variado com supermercado, farmácia, fast food, bares, restaurantes e serviço de carretos.

Observa-se também o Centro Hospitalar do Mandaqui, com uma grande área vegetada, junto à praça Reinaldo Proetti e a praça Rotary. Na praça Rotary encontra-se a Biblioteca Pedro Nava, que está cercada, de um lado um play-ground com equipamentos para a $3^{a}$ idade e do outro um conjunto de mesas e bancos de concreto sem manutenção. No dia da vistoria não havia ninguém utilizando o play-ground e as mesas e bancos de concreto.

Na praça Reinaldo Proetti, a ciclovia corre ao longo do canteiro central arborizado sobre o rio canalizado e tamponado. 


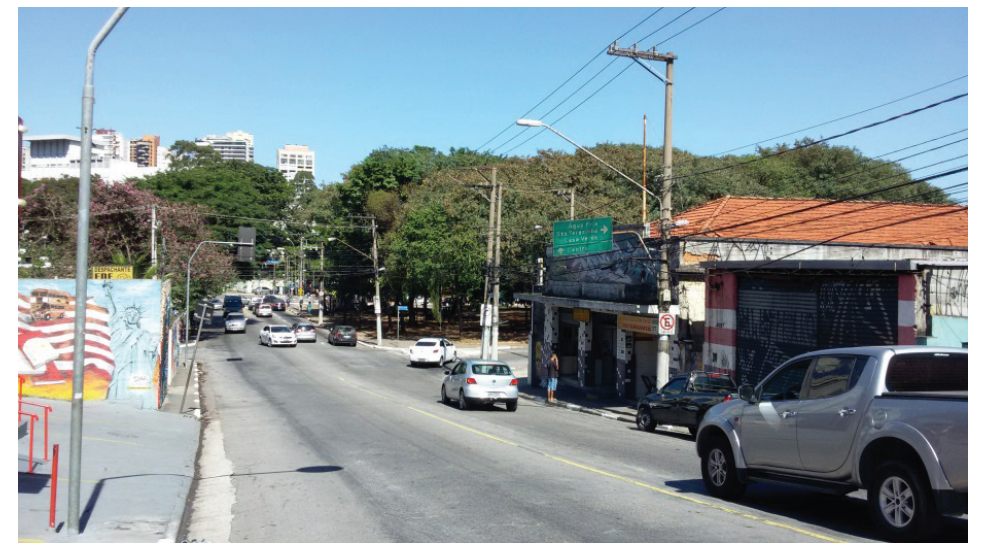

Figura 17 - Rua Voluntários da Pátria com vista para a praça do Rotary. Fonte: Natalia Carvalho em 02/05/16

\section{Trecho 3: Avenida Imirim}

Neste trecho é observado uma predominância de residências com padrão médio/baixo e galpões com comércio variado de grande porte como concessionárias, depósito de material de construção, auto-peças, supermercado e loja de veículos usados. Encontram-se também alguns equipamentos urbanos públicos como escolas.

No trecho do rio canalizado e tampado há uma área arborizada e vegetada com ciclovia e nos trechos mais estreitos há ciclofaixa nos dois sentidos da avenida Eng ${ }^{\circ}$ Caetano Álvares.

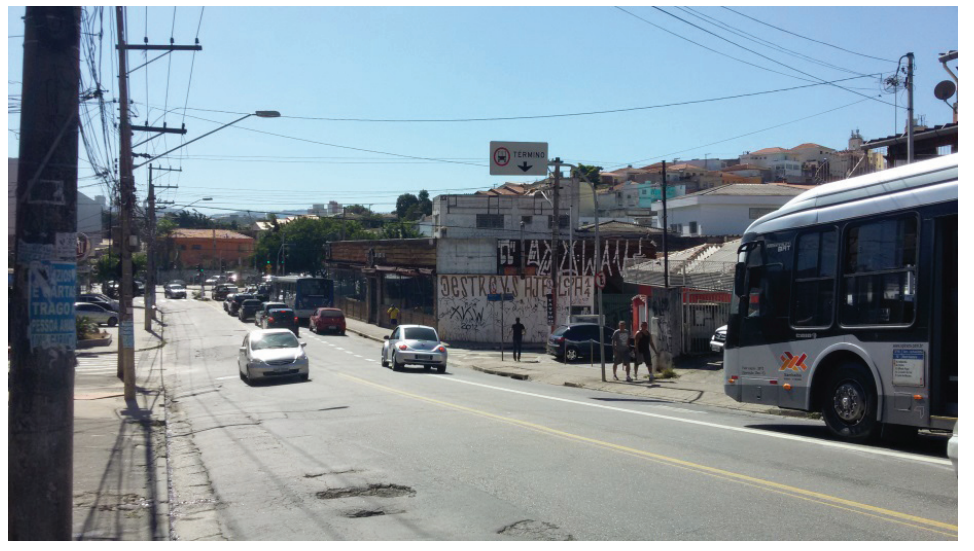

Figura 18 - Avenida Imirim próxima à Av. Eng. Caetano Álvares.

Fonte: Natalia Carvalho em 02/05/16

\section{Trecho 4: Avenida Casa Verde}

Neste trecho, observamos uma predominância de residências com padrão médio, galpões com comércio variado de grande porte como concessionárias, depósito de 
material de construção, auto-peças, supermercado, loja de veículos usados, escola de tênis e restaurante. Neste trecho há uma escola estadual.

O rio vem canalizado e tampado até a rua Orense, depois o rio prossegue aberto e canalizado com contrafortes de concreto. A ciclofaixa, sem nenhum tipo de vegetação ou árvore, corre paralela ao canal junto à avenida eng ${ }^{\circ}$ Caetano Álvares e acaba ou inicia na avenida Casa Verde. Na avenida Mandaqui inicia ou termina uma ciclo faixa, mas não há ligação entre ambas.

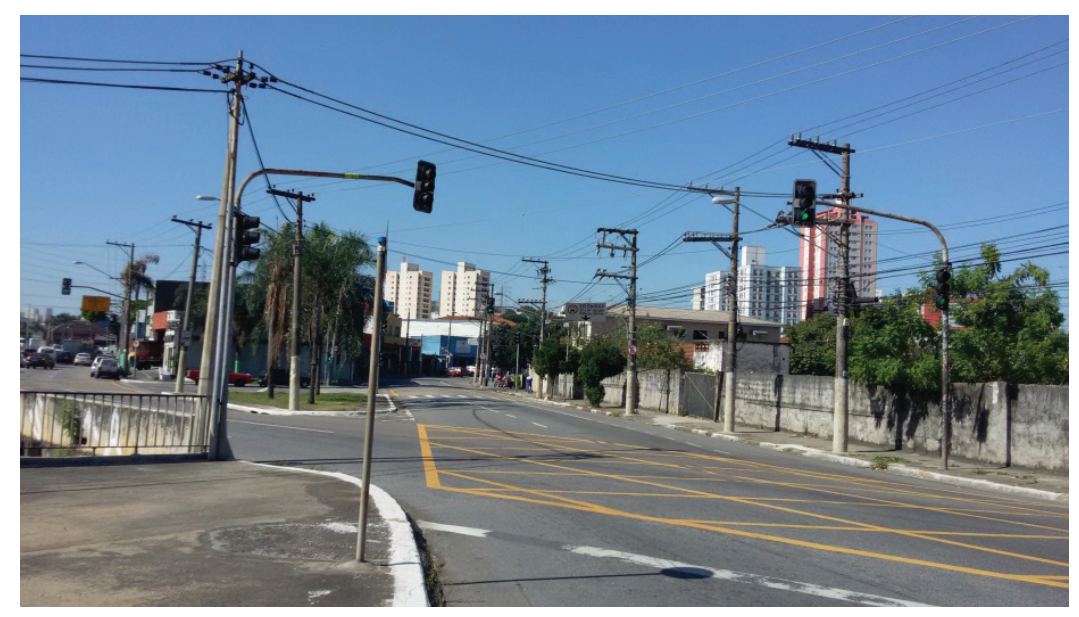

Figura 19 - Cruzamento da Avenida Casa Verde com a Av. Eng. Caetano Álvares. Fonte: Natalia Carvalho em 02/05/16

\section{Percepção Climática}

Analisando o Atlas Ambiental do município de São Paulo, observamos que no trecho da rua Voluntários da Pátria a temperatura é de $30 \% 30.5^{\circ}$ e nos trechos da avenida Imirim e avenida Casa Verde a temperatura é de $29^{\circ}$ e $29.5^{\circ}$.

Na vistoria foi observado o contrário, sendo o trecho da rua Voluntários da Pátria, o trecho mais arborizado uma temperatura mais amena e subindo a temperatura até o trecho da avenida Casa e Verde, onde praticamente não existe arborização e o canal aberto e os contrafortes foram executados em estrutura de concreto.

A Figura 20 a seguir apresenta a variação climática na Zona Norte de São Paulo, de acordo com o Altas Ambiental do município. 


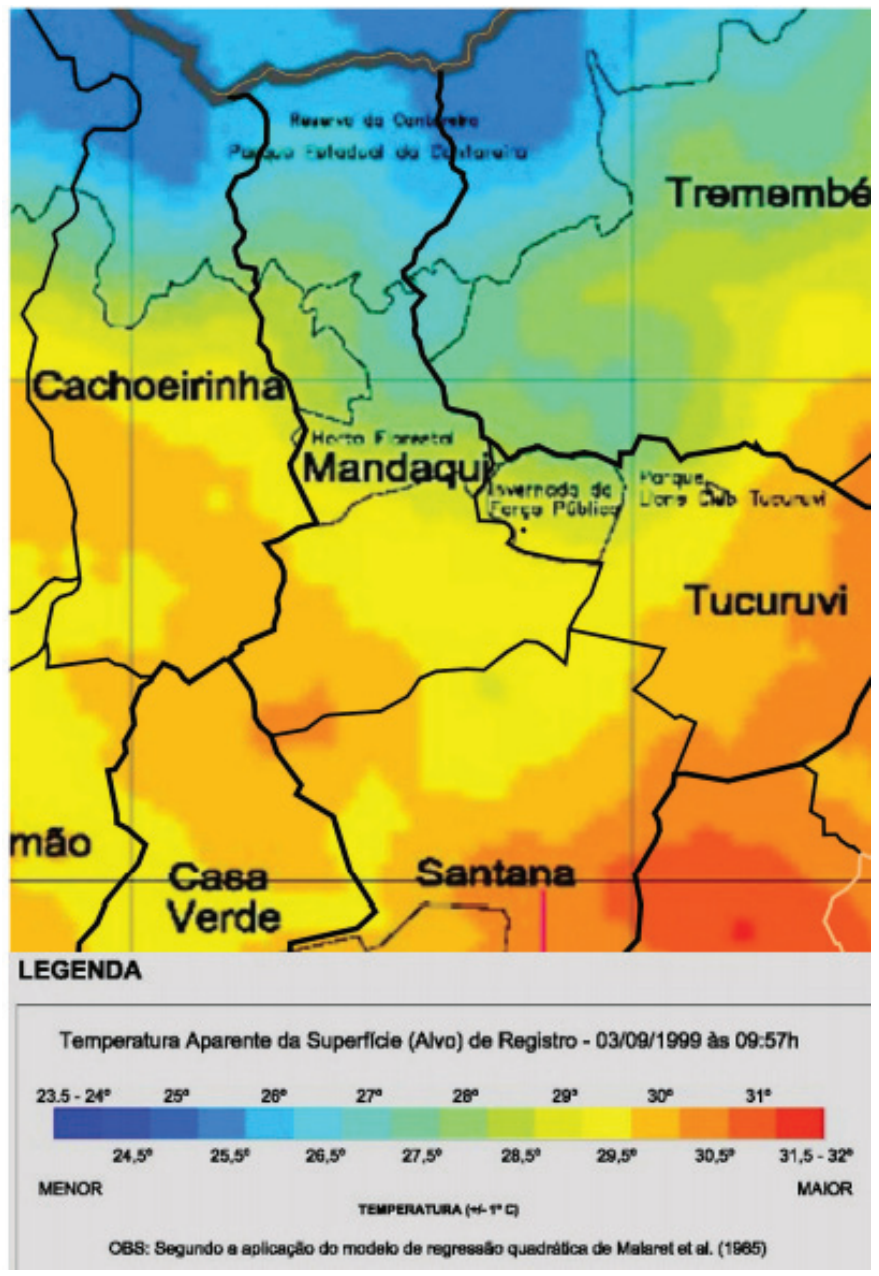

Figura 20 - Mapa das ilhas de calor. Fonte: Atlas Ambiental do Município de São Paulo.

\section{Percepção da Cobertura Vegetal}

Ao longo do Trecho entre a Rua Voluntários da pátria e a Avenida da Casa Verde, seguindo a calha do Ribeirão Mandaqui é percebido uma arborização urbana convencional. As espécies arbóreas observadas não demonstram diversidade de espécies.

As manchas de vegetação existentes não possuem mais a configuração da mata original, como é observada nos pontos de vegetação mais preservada no extremo norte, na Serra da Cantareira.

No cruzamento da Rua Voluntários da Pátria com a Avenida Caetano Álvares há a Praça do Rotary Clube, que abriga uma biblioteca pública e uma área de convívio, e do lado oposto há a Praça Américo, contigua ao Conjunto Hospitalar do Mandaqui, com uma extensa área verde permeável. A Figura 21 apresenta a sua localização. 


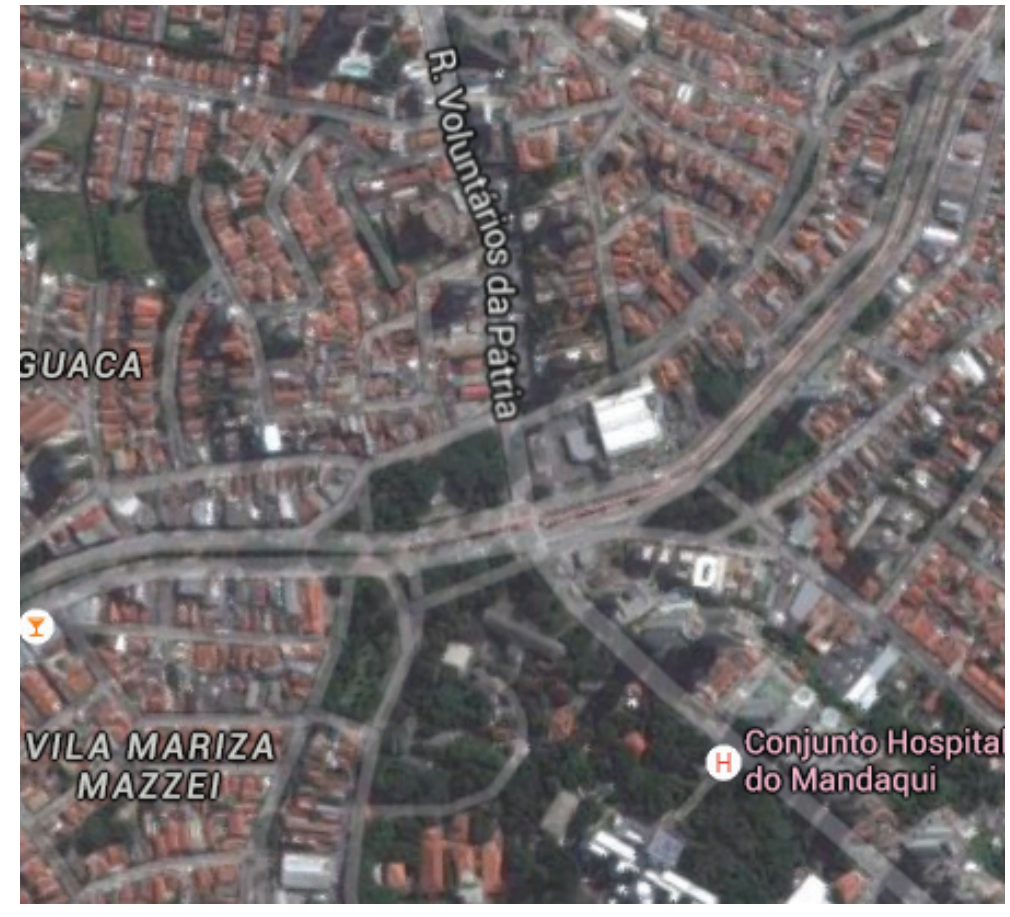

Figura 21 - Rua Voluntários da Pátria com a Avenida Caetano Álvares. Fonte: Google maps. Acesso em 22/03/2016

A poucos metros dali, na Rua Pelegrino foi observado um córrego com águas claras correndo sobre um leito natural. Há um descarte irregular de resíduos sólidos no local. Foram observadas espécies arbóreas de grande porte, sem estratificação vertical, inclusive exóticas agressivas, como a Leucena. Este córrego apresenta um grande potencial para a recuperação e percepção dos rios dentro do contexto urbano.

No trecho entre a Avenida Voluntários da Pátria e a Avenida Imirim as praças dão lugar a um comércio diverso, onde foram observados bancos, restaurantes e lojas em geral. A arborização presente no local se confina no canteiro central e em pequenos canteiros verdes em algumas esquinas. No raio de 500 metros do eixo da Avenida Caetano Álvares é observado pequenos lotes com casinhas antigas que ocupam todo o terreno, sem ajardinamento ou arborização nas calçadas.

Próximo a Avenida Imirim, o tecido urbano contrasta com uma mancha verde solitária presente na quadra da Escola E.E. Augusto Meireles Filho. A Figura 22 apresenta a sua localização. 


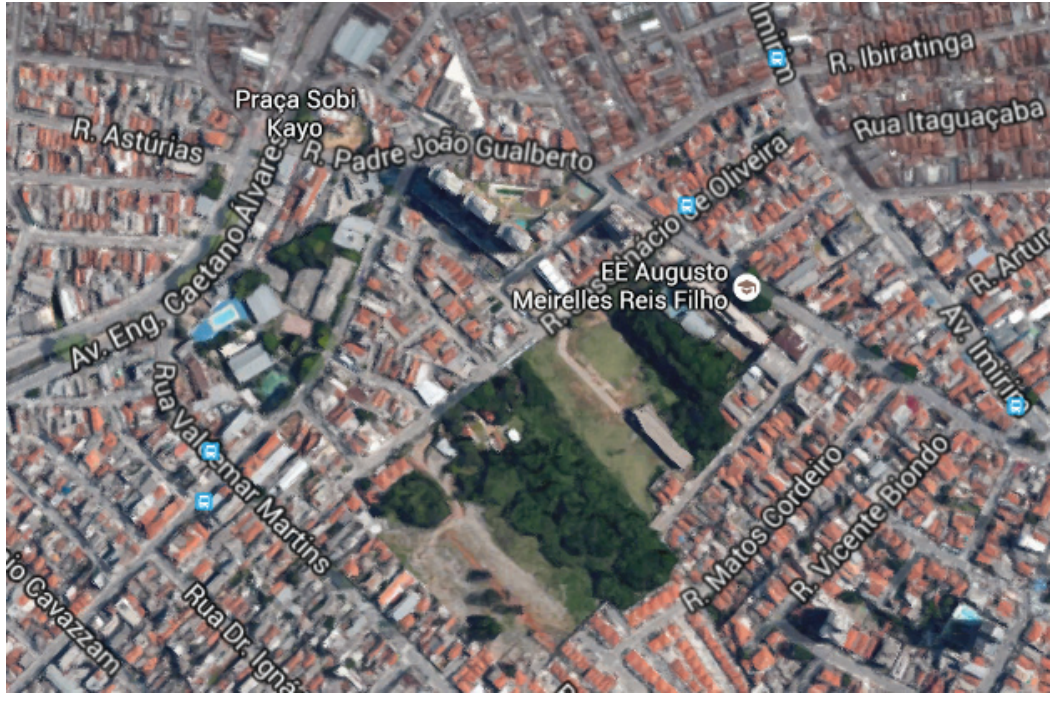

Figura 22 - Avenida Imirim com a Avenida Caetano Álvares. Fonte: Google maps

Entre a Avenida Imirim e a Avenida da Casa Verde, a cobertura vegetal vai ficando cada vez mais escassa. O comércio se transforma em de venda e manutenção de automóveis e grandes galpões. Onde o Ribeirão Mandaqui emerge é observada a ruptura do verde presente anteriormente no canteiro central, dando lugar a um canal concretado que engessa o rio entre duas avenidas. Não há nenhum resquício de vegetação ao longo da Avenida Caetano Álvares.

Em uma primeira análise, verifica-se que o Ribeirão Mandaqui não apresenta nenhuma característica natural de suas funções ecológicas. Perde-se toda a faixa de APP para as Avenidas, tirando das pessoas a relação com o Rio. $O$ ambiente é árido e inquietante. A Figura 23 apresenta a sua localização.

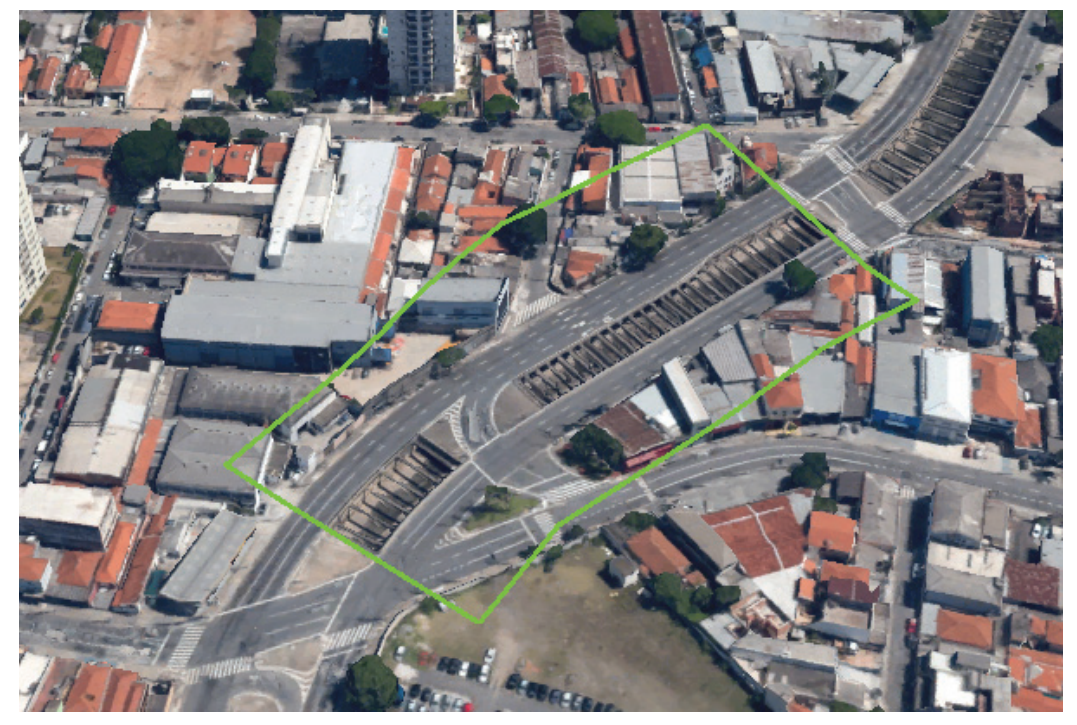

Figura 23 - Avenida da Casa Verde com a Avenida Caetano Álvares. Detalhe para a representação da APP de 30 metros Fonte: Google maps 


\section{CONSIDERAÇÕES FINAIS}

A vegetação arbórea executa funções ecossistêmicas de sequestro de carbono, especialmente de carbono húmico, indicador funcional dos serviços ambientais de drenagem, oferecendo serviços ambientais necessários para a manutenção do lençol freático.

Por meio da aferição de índices indicadores de funcionalidade em trechos de floresta urbana, é possível entender o grau de implantação do fluxo vertical de energia e matéria nessas áreas, bem como a propensão da área para a prestação de serviços ecossistêmicos urbanos. Com base neles, podem ser traçadas metas objetivas de recuperação ambiental, para o monitoramento da eficácia de intervenções paisagísticas.

Em relação à concepção de projetos voltados para a melhoria ou introdução de serviços ecossistêmicos, adotar como referência um modelo florestal. Tais áreas abrigam os atributos necessários para a implantação do ciclo biológico de carbono e paralelo de nutrientes e a potencialidade de se formar um corredor ecológico através da restauração florestal das Áreas de Preservação Permanente do Ribeirão do Mandaqui, áreas lindeiras dentro da microbacia que possuem potencial recuperação florestal e Unidades de Conservação e Parques Urbanos na Zona Norte de São Paulo.

Entende-se que a absorção de carbono por ecossistemas terrestres é a chave para a prestação de serviços ecossistêmicos urbanos. Com base nisso, este estudo se propõe a elucidar características do sequestro de carbono em trechos diferenciados de floresta urbana, configurados por intervenções paisagísticas distintas.

Sugerem-se então as seguintes diretrizes:

1. incrementar áreas com concepção paisagística semelhante a de estratos florestais, a fim de melhorar seu desempenho na prestação de serviços ecossistêmicos urbanos na Área de Preservação Permanente do Ribeirão do Mandaqui e áreas verdes com potencial para a restauração florestal;

2. rever os tratos silviculturais utilizados em áreas verde publicas, praças e parques. A manutenção da serapilheira viabilizaria a implantação completa do ciclo de carbono e o paralelo de nutrientes, melhorando o desempenho ambiental do trecho; 
3. analisar quimicamente o solo das áreas gramadas na microbacia. Aquelas com altas concentrações de ácidos húmicos são mais propícias à recuperação do que aquelas com elevados teores de isótopo 13;

4. analisar a ligação de trechos de floresta urbana e arborização existente na bacia com base na análise de mobilidade pedestriana,

5. valorar o impacto econômico, social e ambiental na criação de um corredor ecológico na microbacia do Ribeirão do Mandaqui.

\section{BIBLIOGRAFIA}

AB' SÁBER, A.N. O mosaico primário de matas e cerrados do Planalto Paulistano. Cadernos de Ciências da Terra 6:24-26. 1970

AB' SÁBER, A.N. Originalidade do sítio da cidade de São Paulo. Acrópole 295/296:239246. 1963

AB'SABER, Aziz N.. Geomorfologia do sítio urbano de São Paulo. Cotia, Ateliê Editorial, 2007, 336p

AHPCE - Associação Holística de Participação Comunitária Ecológica agora Instituto Auá de Empreendedorismo Socioambiental. Avaliação Ecossistêmica Subglobal RBCV. Acesso 12/07/2016. http://redepapelsolidario.org.br/ahpce-associacao-holisticade-participacao-comunitaria-ecologica-agora-instituto-aua-de-empreendedorismosocioambiental/

AMARAL, Rubens do. A prestação de serviços ecossistêmicos e a dinâmica de estoque de dióxido de carbono no Sistema de Espaços Livres do Município de Belo Horizonte: estudo de caso na Regional CentroSul. Dissertação (mestrado) - Universidade Federal de Minas Gerais, Escola de Arquitetura. Belo Horizonte, MG. 185p. 2015.

ARAGAKI, S. \& MANTOVANI, W. 1998. Caracterização do clima e da vegetação de remanescente florestal no Planalto Paulistano (SP). In Anais do IV Simpósio de Ecossistemas Brasileiros (S. Watanabe, coord.). Academia de Ciências do Estado de São Paulo. v.2, p.25-36. Editora Imprensa Oficial. 2004. 
ARAGAKI, S. \& MANTOVANI, W. Estudos estruturais e taxonômicos de trecho remanescente de floresta no Parque Municipal Alfredo Volpi (São Paulo, SP). In Anais do III Simpósio de Ecossistemas da Costa Brasileira (S. Watanabe, coord.). Academia de Ciências do Estado de São Paulo. v.2, p.68-80. 1994.

ARRUDA, Moacir Bueno. Gestão Integrada de Ecossistemas aplicada a Corredores Ecológicos. Brasília, IBAMA 472 p. 2005.

BALÉE, W. Cultura na vegetação da Amazônia brasileira. In: NEVES, W. (Org.) Biologia e ecologia humana na Amazônia: avaliação e perspectivas e ecologia humana na Amazônia. Belém: Sociologias, 1989. p. 95-109

BONDAR, Camila Simhon e HANNES, Evy. Infraestrutura verde para o bairro do Mandaqui: possibilidade ou utopia? Revista LABVERDE n9 - Artigo 02 Dezembro de 2014

CABRAL, Arthur Simões Caetano. Os Córregos Ocultos e Seus Resquícios nos Espaços Livres Urbanos: Os Afluentes do Córrego Mandaqui. PAISAGEM E AMBIENTE: ENSAIOS - N. 35 - SÃO PAULO - P. 63 - 87 - 2015

CARVALHO, Natalia Rezende. Princípios da Ecologia de Paisagem e a Prestação de Serviços Ecossistêmicos para a Microbacia do Ribeirão do Mandaqui. Revista Labverde. FAU USP, 2016

CONSTRUBASE. Imagem Acesso 23/03/2016 http://www.construbase.com.br/areasde-atuacao/construcoes/mandaqui.php

DISLICH, R; CERSÓSIMO, L., MANTOVANI, W. 2001. Análise da estrutura de fragmentos florestais no Planalto Paulistano - SP. Revista Brasil. Bot., São Paulo, V.24, n.3, p.321-332, set. 2001

EITEN, G. A vegetação do Estado de São Paulo. Boletim do Instituto de Botânica de São Paulo, v.7, p.1-147, 1970.

FARR, Douglas. Sustainable Urbanism: Urban Design With Nature. BOOKMAN. 352p. 2007. 
FRANCO, Maria de Assunção Ribeiro. Desenho Ambiental - Introdução à Arquitetura da Paisagem com o Paradigma Ecológico. 2ª . Edição, São Paulo, Annablume: Fapesp, 2008.

FRANCO, Maria de Assunção Ribeiro. Infraestrutura Verde em São Paulo: o caso do Corredor Verde Ibirapuera-Villa Lobos. Revista LABVERDE, p. 135-154, 2010.

FUNDAÇÃO SOS MATA ATLÂNTICA. Atlas dos Remanescentes Florestais da Mata Atlântica. Período 2012-2013. Fundação SOS Mata Atlântica, e Instituto Nacional de Pesquisas Espaciais - INPE). . São Paulo, 2014

FUNDAÇÃO SOS MATA ATLÂNTICA; Instituto Nacional de Pesquisas Espaciais. Atlas dos Remanescentes Florestais e Ecossistemas Associados no Domínio da Mata Atlântica. São Paulo. 2000

GAZETA ZONA NORTE. Imagem Acesso 22/03/2016 http://www.gazetazn.com.br/ index 1. asp? $\mathrm{bm}=\mathrm{m} \& \mathrm{ed}=136 \& \mathrm{~s}=147 \& \mathrm{ma}=828 \& \mathrm{c}=0 \& \mathrm{~m}=0$

GEOSAMPA Imagens de satélite do município de São Paulo. 2016. Acesso em: maio. 2016.

GOMES, E.P.C. Fitossociologia do componente arbóreo de um trecho de mata em São Paulo, SP. Dissertação de mestrado, Universidade de São Paulo, São Paulo. 1992.

GOOGLE EARTH. Imagens de satélite do município de São Paulo. 2016. Acesso em: maio. 2016.

HOBBS, R. J.; HARRIS, R. J. Restoration Ecology: Repairing the Earth's Ecosystems in the New Millennium. Restoration Ecology, v. 9, n. 2, p. 239-246, 2001.

HOBBS, R. J.; NORTON, D. A. Towards a conceptual framework for restoration ecology. Restoration ecology, v. 4, p. 93-110, 1996

HUECK, K. Distribuição e habitat natural do Pinheiro do Paraná (Araucaria angustifolia). Boletim da Faculdade de Filosofia, Ciências e Letras da Universidade de São Paulo, Botânica, 10:1-24. 1953.

IBGE. Mapa de Biomas do Brasil, primeira aproximação. Rio de Janeiro: IBGE. Acessível em www.ibge.gov.br. 2004. 
IUCN. 2003 IUCN Red List of Threatened Species. < http://www.redlist.org>. 2003.

KUSER, John E. Urban And Community Forestry In The Northeast. Springer Science \& Business Media, 487 p. 2006

LOVELL, S. T.; TAYLOR, J. R. Supplying urban ecosystem services through multifunctional green infrastructure in the united states. Landscape Ecology in Review, Illinois, v. 28, p. 1447-1463, 2013.

MAGALHÃES Luís Mauro S. Arborização e Florestas Urbanas -Terminologia Adotada para a Cobertura Arbórea das Cidades Brasileiras. Série Técnica Floresta e Ambiente. Departamento de Ciências Ambientais, Instituto de Florestas, UFRRJ, Seropédica, RJ. p.23-26. 2006

MANTOVANI, W. Cobertura Vegetal do Município de São Paulo. Prefeitura do Município de São Paulo, São Paulo. Relatório Interno da Secretaria do Meio Ambiente da Prefeitura do Município de São Paulo. Atlas Ambiental do Município de São Paulo. 32 p 2000.

METZGER, Jean Paul O Que é Ecologia De Paisagens? Laboratório de Ecologia de Paisagens e Conservação - LEPaC Departamento de Ecologia, Instituto de Biociências USP Biota Neotropica. 2001.

MONBIOT, George. If children lose contact with nature they won't fight for it. November, 2012. Fonte: https://www.theguardian.com/commentisfree/2012/nov/19/childrenlose-contact-with-nature

MYERS, N., MITTERMEYER, R.A., FONSECA, G.A.B., \& KENT, J. Biodiversity hotspots for conservation priorities. Nature 403: 853-858. 2000

PELLEGRINO, Paulo R. M. Pode se planejar a paisagem? Paisagem e Ambiente Ensaios. São Paulo: FAUUSP, n. 21, 2000.

PONCIANO, Levino. Os bairros de São Paulo de A a Z. 1ed. São Paulo: Senac, 2001.

SÃO PAULO (Estado) Secretaria do Meio Ambiente/Secretaria Municipal de Planejamento. Vegetação Significativa do Município de São Paulo, São Paulo, 1988. 
SÃO PAULO (Município), Secretaria do Vede e de Meio Ambiente/Departamento de Parques e Áreas Verdes. Guia dos Parques Municipais de São Paulo, São Paulo, 2010.

SÃO PAULO (Município), Secretaria Municipal de Planejamento Urbano /Secretaria Municipal do Verde e Meio Ambiente. Atlas Ambiental do Município de São Paulo. São Paulo, 2002.

SÃO PAULO ANTIGA. Imagem Acesso 22/03/2016 http://www.saopauloantiga.com. br/avenida-casa-verde-2012/

SÃO PAULO ANTIGA. Imagem Acesso 22/03/2016 http://www.saopauloantiga.com. br/avenida-casa-verde-2012/

SÃO PAULO, Governo do Estado. Unidades de Conservação do Estado de São Paulo. Instituto Florestal, Fundação Florestal, 2016.

SOUZA, D. T. P. Corredores Verdes: Uma Abordagem para o seu Planejamento em Municípios Brasileiros de Pequeno Porte. Dissertação (Mestrado em Engenharia Civil) Programa de Pós-Graduação em Engenharia Civil, UFRGS, Porto Alegre, 2012.

UNESCO, 1994 Fonte: http://iflorestal.sp.gov.br/files/2013/03/certif.jpg

YAZBEK, Priscila. Quer listar os bairros mais caros de SP? Conte suas árvores. Revista Exame. 12/03/2016. Acesso em 23/05/2016 http://exame.abril.com.br/seu-dinheiro/ noticias/quer-conhecer-os-bairros-mais-caros-de-sp-conte-suas-arvores 